Article

\title{
Design, Synthesis, and Structure-Activity Relationships of Thiazole Analogs as Anticholinesterase Agents for Alzheimer's Disease
}

\author{
Begüm Nurpelin Sağlık ${ }^{1,2}$, Derya Osmaniye ${ }^{1,2}$, Ulviye Acar Çevik ${ }^{1,2}$, Serkan Levent ${ }^{1,2}{ }^{(}$, \\ Betül Kaya Çavuşoğlu ${ }^{3}$, Yusuf Özkay ${ }^{1,2}$ ) and Zafer Asım Kaplancıkı 1,*(1) \\ 1 Department of Pharmaceutical Chemistry, Faculty of Pharmacy, Anadolu University, 26470 Eskişehir, Turkey; \\ bnsaglik@anadolu.edu.tr (B.N.S.); dosmaniye@anadolu.edu.tr (D.O.); uacar@anadolu.edu.tr (U.A.Ç.); \\ serkanlevent@anadolu.edu.tr (S.L.); yozkay@anadolu.edu.tr (Y.Ö.) \\ 2 Doping and Narcotic Compounds Analysis Laboratory, Faculty of Pharmacy, Anadolu University, \\ 26470 Eskişehir, Turkey \\ 3 Department of Pharmaceutical Chemistry, Faculty of Pharmacy, Zonguldak Bülent Ecevit University, \\ 67600 Zonguldak, Turkey; betul.kcavusoglu@beun.edu.tr \\ * Correspondence: zakaplan@anadolu.edu.tr; Tel.: +90-222-335-0580/3777
}

Received: 12 August 2020; Accepted: 18 September 2020; Published: 20 September 2020

\begin{abstract}
Dementia is a neurological condition commonly correlated with Alzheimer's disease (AD), and it is seen with many other central nervous system (CNS) disorders. The restricted number of medications is not appropriate to offer enough relief to enhance the quality of life of patients suffering from this symptom; thus, all therapeutic choices should be carefully assessed. In this study, new thiazolylhydrazone derivatives (2a-2l) were designed and synthesized based on the cholinergic hypothesis. Their chemical structures were confirmed by ${ }^{1} \mathrm{H} N M R,{ }^{13} \mathrm{C} N M R$, and HRMS spectrometric techniques. The ADME (absorption, distribution, metabolism, elimination) parameters of the synthesized compounds were predicted by using QikProp 4.8 software. It was concluded that all compounds presented satisfactory drug-like characteristics. Furthermore, their inhibitory activities against acetylcholinesterase (AChE) and butyrylcholinesterase (BChE) in vitro were also tested by modified the Ellman spectrophotometric method. According to the results, all compounds showed a weak inhibitory effect on BChE. On the other hand, most of the compounds (2a, 2b, 2d, 2e, $2 \mathbf{g}, \mathbf{2} \mathbf{i}$, and $2 \mathbf{j}$ ) had a certain AChE inhibitory activity, and the $\mathrm{IC}_{50}$ values of them were calculated as $0.063 \pm 0.003,0.056 \pm 0.002,0.147 \pm 0.006,0.040 \pm 0.001,0.031 \pm 0.001,0.028 \pm 0.001$, and 0.138 $\pm 0.005 \mu \mathrm{M}$, respectively. Among these derivatives, compound $2 \mathbf{i}$ was found to be the most active agent in the series with an $\mathrm{IC}_{50}$ value of $0.028 \pm 0.001 \mu \mathrm{M}$, which indicated an inhibition profile at a similar rate as the reference drug, donepezil. The potential binding modes of compounds $2 \mathbf{a}, \mathbf{2} \mathbf{b}, \mathbf{2 e}$, $2 \mathrm{~g}$, and $\mathbf{2 i}$ with $\mathrm{AChE}$ were investigated and compared with each other by the molecular docking studies. The results showed that these compounds were strongly bound up with the AChE enzyme active site with the optimal conformations.
\end{abstract}

Keywords: ADME parameters; Alzheimer's disease; anticholinesterase enzyme activity; molecular docking; thiazole

\section{Introduction}

Alzheimer's disease (AD), the most common type of dementia [1], is an irreversible, progressive brain disease that has destructive effects on memory and thinking [2]. The most frequent symptoms of $\mathrm{AD}$ are impairment in the formation of the short-term memory, problems in language skills, and attention deficits. Personality change, deterioration of visuospatial skills, anxiety, and depression 
are common during the course of the disease. Patients eventually lose the ability to be self-supportive and become bedridden. The survival of the disease is $8-10$ years, and death usually occurs due to complications that result from immobility and malnutrition [3].

Although there are many hypotheses about the pathophysiology of the disease, its pathogenesis cannot be fully explained [4]. The cholinergic system [5], beta amyloid (A $\beta$ ) protein [6], tau protein, oxidative stress [7], inflammation [8], and toxic metal ions [9] are the main hypotheses that explain the causes and progression of AD. In line with these hypotheses, increasing cholinergic activity with cholinesterase inhibitory compounds [10], inhibiting A $\beta$ aggregate formation [11], and reducing the hyperphosphorylation of tau protein [12] are the main treatment approaches for the disease. Studies for the treatment of $\mathrm{AD}$ have focused primarily on cholinesterase $(\mathrm{ChE})$ inhibitors, which ensure the regulation of cholinergic conduction. The acetylcholine (ACh) is the main neurotransmitter of the cholinergic system, and its hydrolysis into choline and acetic acid is catalyzed by acetylcholinesterase (AChE). The cholinergic hypothesis is based on the presumption that the inhibition of AChE would prevent the hydrolysis of ACh, so that the level of ACh in cholinergic synapses is increased. Donepezil, galantimine, and rivastigmine [13] are cholinesterase inhibitors that have been used as drugs approved by the Food and Drug Administration (FDA) for AD [14]. However, the drugs used in the treatment of $\mathrm{AD}$ are only for relieving the symptoms of the disease, and a drug that stops the progression of the disease has not yet been developed. In addition, the currently used drugs have side effects that limit their clinical use. For this reason, scientific studies for the discovery of stronger drugs with fewer side effects for the treatment of AD remain important and continue intensely [15-18].

It is well-known that the AChE enzyme active site structure is important to the development of new $\mathrm{ChE}$ inhibitors. The catalytic anionic site (CAS) and the peripheral anionic binding site (PAS) form the structure of the AChE active site. Chemically, the aromatic groups of the compounds bind to the PAS region, whereas the moieties carrying a basic center interact with the CAS [19,20]. Dual binding inhibitors such as donepezil bind to both sites; therefore, these types of compounds can show a very potent AChE inhibition profile [21-24].

Heterocyclic rings are frequently used as the main structure in the design of biological compounds [25]. It has been demonstrated in several studies that compounds carrying a thiazole ring are effective against neurodegenerative disorders caused by low cholinergic neurotransmitter levels [26-31]. In this paper, we aim to present the new thiazole derivatives as ChE inhibitors. In accordance with this purpose, the thiazole ring and hydrazine moiety, which is thought to act as a basic center, are gathered structurally. So, novel 3-((2-(4-(4-(trifluoromethyl)phenyl)thiazol2-yl)hydrazineylidene)methyl)-substituedphenyl derivatives were designed and synthesized. It is believed that the lipophilic 4-(4-(trifluoromethyl) phenyl)thiazole group can bind to the PAS region; however, the binding to the CAS of the enzyme active site can be provided by the benzylidenehydrazine moiety (Figure 1). Moreover, the hydroxyl and methoxy groups were selected as functional groups inspired by the methoxy groups in donepezil molecule (Scheme 1). Thus, it was aimed to discuss the contribution of functional groups such as these.

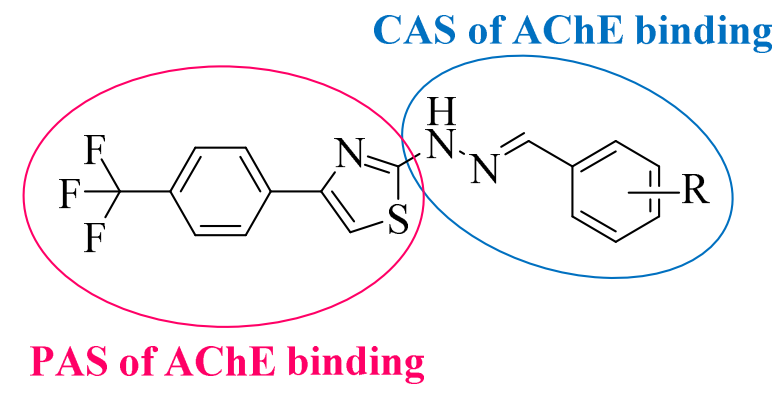

Figure 1. The chemical parts of the target compounds $\mathbf{2 a - 2 l}$ according to the binding to the catalytic anionic site (CAS) and peripheral anionic binding site (PAS) regions. 


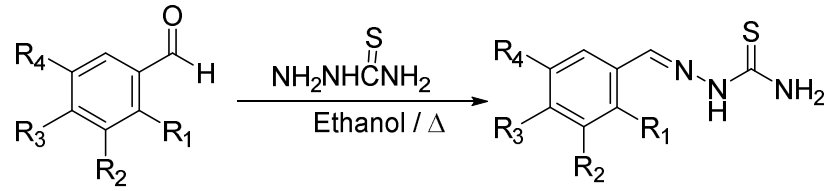

(1a-11)<smiles>[R]c1cc(/C=N\NC(N)=S)cc(/C=N/Nc2nc(-c3ccc(C(F)(F)F)cc3)cs2)c1[R]</smiles>

$(2 \mathrm{a}-2 \mathrm{I})$

\begin{tabular}{|c|c|c|c|c|}
\hline Compounds & $\mathbf{R}_{1}$ & $\mathbf{R}_{2}$ & $\mathbf{R}_{3}$ & $\mathbf{R}_{4}$ \\
\hline $2 a$ & $-\mathrm{H}$ & $-\mathrm{OH}$ & $-\mathrm{H}$ & $-\mathrm{H}$ \\
\hline $2 b$ & $-\mathrm{H}$ & $-\mathrm{H}$ & $-\mathrm{OH}$ & $-\mathrm{H}$ \\
\hline $2 c$ & $-\mathrm{OH}$ & $-\mathrm{OH}$ & $-\mathrm{H}$ & $-\mathrm{H}$ \\
\hline $2 d$ & $-\mathrm{OCH}_{3}$ & $-\mathrm{H}$ & $-\mathrm{H}$ & $-\mathrm{H}$ \\
\hline $2 e$ & $-\mathrm{H}$ & $-\mathrm{OCH}_{3}$ & $-\mathrm{H}$ & $-\mathrm{H}$ \\
\hline $2 f$ & $-\mathrm{OCH}_{3}$ & $-\mathrm{OCH}_{3}$ & $-\mathrm{H}$ & $-\mathrm{H}$ \\
\hline $2 g$ & $-\mathrm{H}$ & $-\mathrm{OCH}_{3}$ & $-\mathrm{OCH}_{3}$ & $-\mathrm{H}$ \\
\hline $2 h$ & \multicolumn{4}{|c|}{ Methylendioxy } \\
\hline $2 \mathbf{i}$ & $-\mathrm{H}$ & $-\mathrm{OH}$ & $-\mathrm{OCH}_{3}$ & $-\mathrm{H}$ \\
\hline $2 j$ & $-\mathrm{OH}$ & $-\mathrm{H}$ & $-\mathrm{H}$ & $-\mathrm{OCH}_{3}$ \\
\hline $2 k$ & $-\mathrm{H}$ & $-\mathrm{OCH}_{3}$ & $-\mathrm{OCH}_{3}$ & $-\mathrm{OCH}_{3}$ \\
\hline 21 & $-\mathrm{H}$ & $-\mathrm{OCH}_{3}$ & $-\mathrm{OH}$ & $-\mathrm{OCH}_{3}$ \\
\hline
\end{tabular}

Scheme 1. Synthesis way of the compounds $\mathbf{2 a}-\mathbf{2 l}$.

\section{Materials and Methods}

\subsection{Chemistry}

All the chemicals used in the synthesis were obtained from Merck (Darmstadt, Germany) or Sigma-Aldrich (St. Louis, MO, USA). A MP90 digital melting point apparatus (Mettler Toledo, OH, USA) was used to determine the melting points of the resulting compounds and was presented uncorrected. The $R_{f}$ values of the synthesized compounds were measured using the solution system of petroleum ether:ethyl acetate (3:1). The obtained view of thin-layer chromatography was also added in the Supplementary Material Figure S7. ${ }^{1} \mathrm{H}$ NMR and ${ }^{13} \mathrm{C}$ NMR spectra were recorded by a Bruker $300 \mathrm{MHz}$ and $75 \mathrm{MHz}$ digital FT-NMR spectrometer (Bruker Bioscience, Billerica, MA, USA) in DMSO- $d_{6}$, respectively. In the NMR spectra, splitting patterns were determined and recognized as follows: s: singlet, d: doublet, t: triplet, dd: double doublet, and m: multiplet. Coupling constants $(J)$ were reported in units of Hertz (Hz). Mass spectra were recorded on an LCMS-IT-TOF (Shimadzu, Kyoto, Japan) equipped with a PDA detector (Supplementary Material Figure S8). Silica gel 60 F254 with thin-layer chromatography (Merck KGaA, Darmstadt, Germany) was used to check the purity of compounds.

\subsubsection{General Procedure for the Synthesis of the Compounds}

Synthesis of Substituted Thiosemicarbazones (1a-11)

A mixture of appropriately substituted benzaldehyde $(0.016 \mathrm{~mol})$ and thiosemicarbazide $(1.456 \mathrm{~g}$, $0.016 \mathrm{~mol})$ was refluxed in EtOH $(100 \mathrm{~mL})$ for $3 \mathrm{~h}$. After completion of the reaction, the mixture was cooled in an ice bath, and the precipitated product was filtered, dried, and recrystallized from the $\mathrm{EtOH}$. 
General Procedures of Target Compounds (2a-2l)

Corresponding substituted thiosemicarbazone (1a-11) $(0.001 \mathrm{~mol})$ and 2-bromo-1-(4-(trifluor omethyl)phenyl)ethan-1-one $(0.001 \mathrm{~mol})$ in $\mathrm{EtOH}(40 \mathrm{~mL})$ were refluxed for $4 \mathrm{~h}$. The mixture was cooled in an ice bath, and the precipitated product was filtered, dried, and recrystallized from the EtOH.

3-[(2-\{4-[4-(Trifluoromethyl)phenyl]thiazol-2-yl\}hydrazineylidene)methyl]phenol (2a) Yield: $81 \% . \mathrm{R}_{\mathrm{f}}=0.604$. M.P.: $249.2-251.8^{\circ} \mathrm{C}$. Purity: $96.8 \% .{ }^{1} \mathrm{H}-\mathrm{NMR}\left(300 \mathrm{MHz}\right.$, DMSO- $\left.d_{6}\right): 6.78-6.82(1 \mathrm{H}, \mathrm{m}$, monosubstituted benzene), $7.06(1 \mathrm{H}, \mathrm{d}, J=7.7 \mathrm{~Hz}$, monosubstituted benzene), $7.12-7.13(1 \mathrm{H}, \mathrm{m}$, monosubstituted benzene), $7.24(1 \mathrm{H}, \mathrm{t}, J=7.8 \mathrm{~Hz}$, monosubstituted benzene), $7.59(1 \mathrm{H}, \mathrm{s}), 7.78(2 \mathrm{H}, \mathrm{d}, J=8.3 \mathrm{~Hz}$, 1,4-disubstituted benzene), $7.98(1 \mathrm{H}, \mathrm{s}), 8.08(2 \mathrm{H}, \mathrm{d}, J=8.0 \mathrm{~Hz}, 1,4$-disubstituted benzene), $9.49(1 \mathrm{H}$, br.s., $-\mathrm{OH}), 12.23$ (1H, br.s., $-\mathrm{NH}) .{ }^{13} \mathrm{C}-\mathrm{NMR}$ (75 MHz, DMSO- $\left.d_{6}\right): \delta=106.9,112.4,117.2,118.4,119.4$, 123.0, $124.8(J=269.9 \mathrm{~Hz}), 126.0(\mathrm{~J}=3.6 \mathrm{~Hz}), 126.5,128.2(J=31.5 \mathrm{~Hz}), 130.3,135.9,138.7,142.3,149.2$, 158.1, 168.9. HRMS $(m / z):[\mathrm{M}+\mathrm{H}]^{+}$calcd for $\mathrm{C}_{17} \mathrm{H}_{12} \mathrm{~N}_{3} \mathrm{OF}_{3} \mathrm{~S}: 364.0726$; found: 364.0727 .

4-[(2-\{4-[4-(Trifluoromethyl)phenyl]thiazol-2-yl\}hydrazineylidene)methyl]phenol (2b) Yield: 79\%. $\mathrm{R}_{\mathrm{f}}=0.472$. M.P.: $244.1-247.0{ }^{\circ} \mathrm{C}$. Purity: 90.6\%. ${ }^{1} \mathrm{H}-\mathrm{NMR}\left(300 \mathrm{MHz}, \mathrm{DMSO}-d_{6}\right): 6.85(2 \mathrm{H}, \mathrm{d}, J=8.6 \mathrm{~Hz}$, 1,4-disubstituted benzene), $7.52(2 \mathrm{H}, \mathrm{t}, J=8.7 \mathrm{~Hz}, 1,4$-disubstituted benzene), $7.56(1 \mathrm{H}, \mathrm{s}), 7.78(2 \mathrm{H}, \mathrm{d}$, $J=8.3 \mathrm{~Hz}, 1$,4-disubstituted benzene), $7.99(1 \mathrm{H}, \mathrm{s}), 8.07(2 \mathrm{H}, \mathrm{d}, J=8.1 \mathrm{~Hz}, 1$,4-disubstituted benzene), $9.28(1 \mathrm{H}$, br.s., $-\mathrm{OH}), 12.04(1 \mathrm{H}$, br.s., $-\mathrm{NH}) .{ }^{13} \mathrm{C}-\mathrm{NMR}\left(75 \mathrm{MHz}, \mathrm{DMSO}-d_{6}\right): \delta=106.6,116.2,124.8$ $(J=270.5 \mathrm{~Hz}), 125.6,126.0(\mathrm{~J}=3.7 \mathrm{~Hz}), 126.5,128.4(\mathrm{~J}=31.3 \mathrm{~Hz}), 128.7,138.5,142.9,148.8,159.3,169.1$. HRMS (m/z): $[\mathrm{M}+\mathrm{H}]^{+}$calcd for $\mathrm{C}_{17} \mathrm{H}_{12} \mathrm{~N}_{3} \mathrm{OF}_{3} \mathrm{~S}$ : 364.0726; found: 364.0739 .

3-[(2-\{4-[4-(Trifluoromethyl)phenyl]thiazol-2-yl\}hydrazineylidene)methyl]benzene-1,2-diol (2c) Yield: 75\%. $\mathrm{R}_{\mathrm{f}}=0.417$. M.P.: $234.2-236.8^{\circ} \mathrm{C}$. Purity: $98.5 \% .{ }^{1} \mathrm{H}-\mathrm{NMR}\left(300 \mathrm{MHz}, \mathrm{DMSO}-d_{6}\right): 6.72(1 \mathrm{H}, \mathrm{t}, J=7.8 \mathrm{~Hz}$, 1,2,3-trisubstituted benzene), $6.84\left(1 \mathrm{H}, \mathrm{dd}, J_{1}=1.6 \mathrm{~Hz}, J_{2}=7.8 \mathrm{~Hz}, 1,2,3\right.$-trisubstituted benzene), 7.12 $\left(1 \mathrm{H}, \mathrm{dd}, J_{1}=1.6 \mathrm{~Hz}, J_{2}=7.9 \mathrm{~Hz}, 1,2,3\right.$-trisubstituted benzene), $7.57(1 \mathrm{H}, \mathrm{s}), 7.78(2 \mathrm{H}, \mathrm{d}, J=8.3 \mathrm{~Hz}$, 1,4-disubstituted benzene), $8.08(2 \mathrm{H}, \mathrm{d}, J=8.0 \mathrm{~Hz}, 1,4$-disubstituted benzene), $8.36(1 \mathrm{H}, \mathrm{s}), 9.33(1 \mathrm{H}$, br.s., $-\mathrm{OH}), 12.25(1 \mathrm{H}$, br.s., $-\mathrm{NH}) .{ }^{13} \mathrm{C}-\mathrm{NMR}\left(75 \mathrm{MHz}\right.$, DMSO- $\left.d_{6}\right): \delta=106.5,116.6,117.3,119.7,120.9$, $124.8(J=269.9 \mathrm{~Hz}), 126.0(\mathrm{~J}=3.6 \mathrm{~Hz}), 126.5,128.0(\mathrm{~J}=31.4 \mathrm{~Hz}), 138.7,141.1,145.1,146.0,149.4,168.6$. HRMS (m/z): $[\mathrm{M}+\mathrm{H}]^{+}$calcd for $\mathrm{C}_{17} \mathrm{H}_{12} \mathrm{~N}_{3} \mathrm{O}_{2} \mathrm{~F}_{3} \mathrm{~S}: 380.0675$; found: 380.0675 .

2-[2-(2-Methoxybenzylidene)hydrazineyl]-4-[4-(trifluoromethyl)phenyl]thiazole (2d) Yield: 78\%. $\mathrm{R}_{\mathrm{f}}=0.833$. M.P.: $223.0-225.9^{\circ} \mathrm{C}$. Purity: $92.4 \% .{ }^{1} \mathrm{H}-\mathrm{NMR}\left(300 \mathrm{MHz}, \mathrm{DMSO}-d_{6}\right): 3.84\left(3 \mathrm{H}, \mathrm{s},-\mathrm{OCH}_{3}\right), 7.00(1 \mathrm{H}, \mathrm{t}$, $J=7.6 \mathrm{~Hz}, 1$,2-disubstituted benzene), $7.08(1 \mathrm{H}, \mathrm{d}, J=8.1 \mathrm{~Hz}, 1$,2-disubstituted benzene), 7.33-7.39 $(1 \mathrm{H}, \mathrm{m}, 1$,2-disubstituted benzene), $7.56(1 \mathrm{H}, \mathrm{s}), 7.75(2 \mathrm{H}, \mathrm{d}, J=8.5 \mathrm{~Hz}, 1$,4-disubstituted benzene), 7.79-7.83 (1H, m, 1,2-disubstituted benzene), $8.04(2 \mathrm{H}, \mathrm{d}, J=8.0 \mathrm{~Hz}, 1$,4-disubstituted benzene), 8.38 $(1 \mathrm{H}, \mathrm{s}), 12.29(1 \mathrm{H}$, br.s., $-\mathrm{NH}) .{ }^{13} \mathrm{C}-\mathrm{NMR}\left(75 \mathrm{MHz}, \mathrm{DMSO}-d_{6}\right): \delta=56.1,106.9,112.2,121.2,122.6,124.7$ $(J=265.2 \mathrm{~Hz}), 125.3,126.0(J=3.6 \mathrm{~Hz}), 128.0(J=31.4 \mathrm{~Hz}), 128.9,131.3,137.7,138.6,149.1,157.6,168.9$. HRMS $(\mathrm{m} / \mathrm{z}):[\mathrm{M}+\mathrm{H}]^{+}$calcd for $\mathrm{C}_{18} \mathrm{H}_{14} \mathrm{~N}_{3} \mathrm{OF}_{3} \mathrm{~S}: 378.0882$; found: 378.0887 .

2-[2-(3-Methoxybenzylidene)hydrazineyl]-4-[4-(trifluoromethyl)phenyl]thiazole (2e) Yield: 80\%. $\mathrm{R}_{\mathrm{f}}=0.799$. M.P.: $238.8-241.0^{\circ} \mathrm{C}$. Purity: $94.5 \% .{ }^{1} \mathrm{H}-\mathrm{NMR}\left(300 \mathrm{MHz}, \mathrm{DMSO}-d_{6}\right): 3.80\left(3 \mathrm{H}, \mathrm{s},-\mathrm{OCH}_{3}\right), 6.94-6.98$ (1H, m, 1,3-disubstituted benzene), 7.20-7.25 (2H, m, 1,4-disubstituted benzene), 7.35 (1H, t, $J=7.8 \mathrm{~Hz}$, 1,3-disubstituted benzene), $7.59(1 \mathrm{H}, \mathrm{s}), 7.76(1 \mathrm{H}, \mathrm{d}, J=8.3 \mathrm{~Hz}, 1,3$-disubstituted benzene), 7.84 $(1 \mathrm{H}, \mathrm{d}, J=8.4 \mathrm{~Hz}, 1,3$-disubstituted benzene), $8.02(1 \mathrm{H}, \mathrm{s}), 8.06(2 \mathrm{H}, \mathrm{d}, J=7.9 \mathrm{~Hz}, 1$,4-disubstituted benzene), $12.35(1 \mathrm{H}$, br.s., $-\mathrm{NH}) .{ }^{13} \mathrm{C}-\mathrm{NMR}\left(75 \mathrm{MHz}\right.$, DMSO- $\left.d_{6}\right): \delta=55.5,107.0,111.6,115.6,119.3$, $124.8(J=268.6 \mathrm{~Hz}), 126.0(\mathrm{~J}=3.6 \mathrm{~Hz}), 127.9(\mathrm{~J}=31.4 \mathrm{~Hz}), 128.9,130.4,136.1,138.7,141.8,149.3,159.9$, 168.9. HRMS $(m / z)$ : $[\mathrm{M}+\mathrm{H}]^{+}$calcd for $\mathrm{C}_{18} \mathrm{H}_{14} \mathrm{~N}_{3} \mathrm{OF}_{3} \mathrm{~S}: 378.0882$; found: 378.0887 .

2-[2-(2,3-Dimethoxybenzylidene)hydrazineyl]-4-[4-(trifluoromethyl)phenyl]thiazole (2f) Yield: 83\%. $\mathrm{R}_{\mathrm{f}}=0.826$. M.P.: $212.5-214.9^{\circ} \mathrm{C}$. Purity: $96.7 \% .{ }^{1} \mathrm{H}-\mathrm{NMR}\left(300 \mathrm{MHz}, \mathrm{DMSO}-d_{6}\right): 3.76\left(3 \mathrm{H}, \mathrm{s},-\mathrm{OCH}_{3}\right), 3.81(3 \mathrm{H}$, $\left.\mathrm{s},-\mathrm{OCH}_{3}\right), 7.03-7.08(1 \mathrm{H}, \mathrm{m}, 1,2,3$-trisubstituted benzene), $7.09(1 \mathrm{H}, \mathrm{d}, J=7.7 \mathrm{~Hz}, 1,2,3$-trisubstituted benzene), 7.34-7.40 $(1 \mathrm{H}, \mathrm{m}, 1,2,3$-trisubstituted benzene), $7.55(1 \mathrm{H}, \mathrm{s}), 7.74(1 \mathrm{H}, \mathrm{d}, J=8.4 \mathrm{~Hz}$, 
1,4-disubstituted benzene), $7.80(1 \mathrm{H}, \mathrm{d}, J=8.4 \mathrm{~Hz}, 1$,4-disubstituted benzene), 8.03-8.07 $(2 \mathrm{H}, \mathrm{m}$, 1,2,3-trisubstituted benzene, Ar-H), $8.32\left(2 \mathrm{H}, \mathrm{d}, J=6.2 \mathrm{~Hz}, 1,2,3\right.$-trisubstituted benzene). ${ }^{13} \mathrm{C}-\mathrm{NMR}$ $\left(75 \mathrm{MHz}, \mathrm{DMSO}-d_{6}\right): \delta=56.1,61.5,93.4,106.9,114.1,116.9,124.5(J=265.4 \mathrm{~Hz}), 124.8,126.5(J=3.6 \mathrm{~Hz})$, $128.0(J=30.5 \mathrm{~Hz}), 128.8,137.7,138.6,147.7,149.1,153.1,167.6$. HRMS $(m / z):[\mathrm{M}+\mathrm{H}]^{+}$calcd for $\mathrm{C}_{19} \mathrm{H}_{16} \mathrm{~N}_{3} \mathrm{O}_{2} \mathrm{~F}_{3} \mathrm{~S}$ : 408.0988; found: 408.0989 .

2-[2-(3,4-Dimethoxybenzylidene)hydrazineyl]-4-[4-(trifluoromethyl)phenyl]thiazole (2g) Yield: 77\%. $\mathrm{R}_{\mathrm{f}}=0.479$. M.P.: $198.6-200.3{ }^{\circ} \mathrm{C}$. Purity: $90.3 \% .{ }^{1} \mathrm{H}-\mathrm{NMR}\left(300 \mathrm{MHz}, \mathrm{DMSO}-d_{6}\right): 3.78(3 \mathrm{H}, \mathrm{s}$, $\left.-\mathrm{OCH}_{3}\right), 3.81\left(3 \mathrm{H}, \mathrm{s},-\mathrm{OCH}_{3}\right), 7.00(1 \mathrm{H}, \mathrm{d}, J=8.4 \mathrm{~Hz}, 1,3,4$-trisubstituted benzene), 7.15-7.19 $(1 \mathrm{H}, \mathrm{m}$, 1,3,4-trisubstituted benzene), 7.25-7.27 $(1 \mathrm{H}, \mathrm{m}, 1,3,4$-trisubstituted benzene), $7.55(1 \mathrm{H}, \mathrm{s}), 7.75(2 \mathrm{H}, \mathrm{d}$, $J=8.4 \mathrm{~Hz}, 1,4$-disubstituted benzene), $7.99(1 \mathrm{H}, \mathrm{s}), 8.05(2 \mathrm{H}, \mathrm{d}, J=8.0 \mathrm{~Hz}, 1$,4-disubstituted benzene), $12.31(1 \mathrm{H}$, br.s., $-\mathrm{NH}) .{ }^{13} \mathrm{C}-\mathrm{NMR}\left(75 \mathrm{MHz}\right.$, DMSO- $\left.d_{6}\right): \delta=55.7,55.9,93.0,106.7,108.7,112.0,120.8,124.7$ $(J=263.6 \mathrm{~Hz}), 126.0(J=3.5 \mathrm{~Hz}), 127.9(J=31.6 \mathrm{~Hz}), 128.8,138.6,142.4,146.6,149.4,150.6,169.0$. HRMS $(m / z):[\mathrm{M}+\mathrm{H}]^{+}$calcd for $\mathrm{C}_{19} \mathrm{H}_{16} \mathrm{~N}_{3} \mathrm{O}_{2} \mathrm{~F}_{3} \mathrm{~S}$ : 408.0988; found: 408.0989.

2-[2-(Benzo[1,3]dioxol-5-ylmethylene)hydrazineyl]-4-[4-(trifluoromethyl)phenyl]thiazole (2h) Yield: 82\%. $\mathrm{R}_{\mathrm{f}}=0.813$. M.P.: $237.2-239.9{ }^{\circ} \mathrm{C}$. Purity: $90.2 \% .{ }^{1} \mathrm{H}-\mathrm{NMR}\left(300 \mathrm{MHz}, \mathrm{DMSO}-d_{6}\right): 6.08(2 \mathrm{H}, \mathrm{s}$, benzo[1,3]dioxol), $6.10(1 \mathrm{H}, \mathrm{d}, J=8.0 \mathrm{~Hz}$, benzo[1,3]dioxol), 7.10-7.13 (1H, $\mathrm{m}$, benzo[1,3]dioxol), 7.23 $(1 \mathrm{H}, \mathrm{d}, J=1.3 \mathrm{~Hz}$, benzo[1,3]dioxol), $7.57(1 \mathrm{H}, \mathrm{s}), 7.76(2 \mathrm{H}, \mathrm{d}, J=8.4 \mathrm{~Hz}, 1,4$-disubstituted benzene), 7.96 $(1 \mathrm{H}, \mathrm{s}), 8.05\left(2 \mathrm{H}, \mathrm{d}, J=8.0 \mathrm{~Hz}, 1,4\right.$-disubstituted benzene), $12.20(1 \mathrm{H}$, br.s., $-\mathrm{NH}) .{ }^{13} \mathrm{C}-\mathrm{NMR}(75 \mathrm{MHz}$, DMSO- $\left.d_{6}\right): \delta=101.9,105.0,106.8,109.0,122.6,124.8(J=269.9 \mathrm{~Hz}), 126.0(J=3.6 \mathrm{~Hz}), 126.5,127.9$ $(J=31.6), 128.9,138.7,141.9,148.4,148.9,149.2,169.0$. HRMS $(m / z):[\mathrm{M}+\mathrm{H}]^{+}$calcd for $\mathrm{C}_{18} \mathrm{H}_{12} \mathrm{~N}_{3} \mathrm{O}_{2} \mathrm{~F}_{3} \mathrm{~S}$ : 392.0675; found: 392.0681 .

2-Methoxy-5-[(2-\{4-[4-(trifluoromethyl)phenyl]thiazol-2-yl\}hydrazineylidene)methyl]phenol (2i) Yield: 78\%. $\mathrm{R}_{\mathrm{f}}=0.375$. M.P.: $226.5-229.8^{\circ} \mathrm{C}$. Purity: $91.1 \% .{ }^{1} \mathrm{H}-\mathrm{NMR}\left(300 \mathrm{MHz}, \mathrm{DMSO}-d_{6}\right): 3.79\left(3 \mathrm{H}, \mathrm{s},-\mathrm{OCH}_{3}\right)$, $6.94(1 \mathrm{H}, \mathrm{d}, J=8.4 \mathrm{~Hz}, 1,3,4$-trisubstituted benzene), 6.98-7.01 (1H, m, 1,3,4-trisubstituted benzene), 7.19-7.20 (1H, m, 1,3,4-trisubstituted benzene), $7.54(1 \mathrm{H}, \mathrm{s}), 7.75(1 \mathrm{H}, \mathrm{d}, J=8.4 \mathrm{~Hz}, 1$,4-disubstituted benzene), $7.82(1 \mathrm{H}, \mathrm{d}, J=8.4 \mathrm{~Hz}, 1$,4-disubstituted benzene), $7.93(1 \mathrm{H}, \mathrm{s}), 8.05(2 \mathrm{H}, \mathrm{d}, J=8.2 \mathrm{~Hz}$, 1,4-disubstituted benzene). ${ }^{13} \mathrm{C}-\mathrm{NMR}\left(75 \mathrm{MHz}, \mathrm{DMSO}-d_{6}\right): \delta=55.9,92.9,106.6,112.1,112.3,119.9$, $124.8(J=269.1 \mathrm{~Hz}), 126.0(J=3.6 \mathrm{~Hz}), 127.5,128.5(J=31.6 \mathrm{~Hz}), 128.8,138.6,142.7,147.2,149.7$, 169.0. HRMS (m/z): $[\mathrm{M}+\mathrm{H}]^{+}$calcd for $\mathrm{C}_{18} \mathrm{H}_{14} \mathrm{~N}_{3} \mathrm{O}_{2} \mathrm{~F}_{3} \mathrm{~S}$ : 394.0832; found: 394.0834 .

4-Methoxy-2-[(2-\{4-[4-(trifluoromethyl)phenyl]thiazol-2-yl\}hydrazineylidene)methyl]phenol (2j) Yield: 75\%. $\mathrm{R}_{\mathrm{f}}=0.688$. M.P.: $252.8-255.1{ }^{\circ} \mathrm{C}$. Purity: $93.2 \% .{ }^{1} \mathrm{H}-\mathrm{NMR}\left(300 \mathrm{MHz}, \mathrm{DMSO}-d_{6}\right): 3.72\left(3 \mathrm{H}, \mathrm{s},-\mathrm{OCH}_{3}\right)$, 6.83-6.84 (2H, m, 1,2,5-trisubstituted benzene), 7.18-7.19 (1H, m, 1,2,5-trisubstituted benzene), 7.57 (1H, s), $7.76(1 \mathrm{H}, \mathrm{d}, J=8.4 \mathrm{~Hz}, 1$,4-disubstituted benzene), $8.06(2 \mathrm{H}, \mathrm{d}, J=8.1 \mathrm{~Hz}, 1,4$-disubstituted benzene), $8.31(1 \mathrm{H}, \mathrm{s}), 9.67(1 \mathrm{H}$, br.s., $-\mathrm{OH}), 12.26(1 \mathrm{H}$, br.s., $-\mathrm{NH}) .{ }^{13} \mathrm{C}-\mathrm{NMR}\left(75 \mathrm{MHz}, \mathrm{DMSO}-d_{6}\right): \delta=55.7,106.7$, 109.9, 117.5, 117.6, 120.8, $124.3(J=270.3 \mathrm{~Hz}), 126.0(J=3.6 \mathrm{~Hz}), 126.5,128.5(J=31.6 \mathrm{~Hz}), 138.7,139.7$, 149.4, 150.5, 152.7, 168.7. HRMS (m/z): $[\mathrm{M}+\mathrm{H}]^{+}$calcd for $\mathrm{C}_{18} \mathrm{H}_{14} \mathrm{~N}_{3} \mathrm{O}_{2} \mathrm{~F}_{3} \mathrm{~S}$ : 394.0832; found: 394.0844 .

4-[4-(Trifluoromethyl)phenyl]-2-[2-(3,4,5-trimethoxybenzylidene)hydrazineyl]thiazole (2k) Yield: 79\%. $\mathrm{R}_{\mathrm{f}}=0.493 . \quad$ M.P.: $141.9-143.8{ }^{\circ} \mathrm{C}$. Purity: $91.7 \% .{ }^{1} \mathrm{H}-\mathrm{NMR}\left(300 \mathrm{MHz}, \mathrm{DMSO}-d_{6}\right): 3.69(3 \mathrm{H}, \mathrm{s}$, $\left.-\mathrm{OCH}_{3}\right), 3.83\left(6 \mathrm{H}, \mathrm{s},-\mathrm{OCH}_{3}\right), 6.98(2 \mathrm{H}, \mathrm{s}), 7.59(1 \mathrm{H}, \mathrm{s}), 7.76(2 \mathrm{H}, \mathrm{d}, J=8.4 \mathrm{~Hz}, 1$,4-disubstituted benzene), $7.98(1 \mathrm{H}, \mathrm{s}), 8.06(2 \mathrm{H}, \mathrm{d}, J=8.1 \mathrm{~Hz}, 1$,4-disubstituted benzene), 12.29 (1H, br.s., $-\mathrm{NH}) .{ }^{13} \mathrm{C}-\mathrm{NMR}$ (75 MHz, DMSO- $\left.d_{6}\right): \delta=56.2,56.3,60.5,103.9,106.9,124.3(J=270.2 \mathrm{~Hz}), 126.0(J=3.6 \mathrm{~Hz}), 126.4$, $128.4(J=36.1 \mathrm{~Hz}), 130.3,138.7,139.0,141.9,149.3,153.6,168.9$. HRMS $(m / z):[\mathrm{M}+\mathrm{H}]^{+}$calcd for $\mathrm{C}_{20} \mathrm{H}_{18} \mathrm{~N}_{3} \mathrm{O}_{3} \mathrm{~F}_{3} \mathrm{~S}: 438.1094$; found: 438.1089 .

2,6-Dimethoxy-4-[(2-\{4-[4-(trifluoromethyl)phenyl]thiazol-2-yl\}hydrazineylidene)methyl]phenol (21) Yield: $76 \% . \mathrm{R}_{\mathrm{f}}=0.208$. M.P.: $248.0-250.1^{\circ} \mathrm{C}$. Purity: $93.8 \% .{ }^{1} \mathrm{H}-\mathrm{NMR}\left(300 \mathrm{MHz}, \mathrm{DMSO}-d_{6}\right): 3.81(6 \mathrm{H}, \mathrm{s}$, $\left.-\mathrm{OCH}_{3}\right), 6.95(2 \mathrm{H}, \mathrm{s}), 7.54(1 \mathrm{H}, \mathrm{s}), 7.76(2 \mathrm{H}, \mathrm{d}, J=8.4 \mathrm{~Hz}, 1,4$-disubstituted benzene), $7.94(1 \mathrm{H}, \mathrm{s}), 8.06$ $\left(2 \mathrm{H}, \mathrm{d}, J=8.1 \mathrm{~Hz}, 1,4\right.$-disubstituted benzene), $8.84(1 \mathrm{H}$, br.s., $-\mathrm{OH}), 12.13(1 \mathrm{H}$, br.s., $-\mathrm{NH}) .{ }^{13} \mathrm{C}-\mathrm{NMR}$ $\left(75 \mathrm{MHz}, \mathrm{DMSO}-d_{6}\right): \delta=56.3,56.4,104.2,106.5,124.3(J=270.3 \mathrm{~Hz}), 125.0,126.0(J=3.6 \mathrm{~Hz}), 126.4,128.4$ 
$(J=31.6 \mathrm{~Hz}), 137.7,138.8,142.6,148.6,149.4,169.0$. HRMS $(m / z):[\mathrm{M}+\mathrm{H}]^{+}$calcd for $\mathrm{C}_{19} \mathrm{H}_{16} \mathrm{~N}_{3} \mathrm{O}_{3} \mathrm{~F}_{3} \mathrm{~S}$ : 424.0937; found: 424.0943 .

\subsection{Cholinesterase Enzymes Inhibition Assay}

The in vitro $\mathrm{AChE}$ and $\mathrm{BChE}$ enzymes inhibition potencies of the synthesized compounds (2a-2l) were evaluated according to the modified Ellman's spectrophotometric method [32]. The reagents and materials used in the enzyme inhibition assay were supplied commercially from Sigma-Aldrich (St. Louis, MO, USA) and Fluka (Steinheim, Germany). The cholinesterase enzyme inhibition procedure was applied as previously reported in our research papers [33-40].

The percentage of inhibition results were displayed as the mean \pm standard deviation (SD). Moreover, the $\mathrm{IC}_{50}$ values were calculated with the help of GraphPad 'PRISM' software (version 5.0) by using a dose-response curve achieved by plotting the percentage inhibition versus the log concentration.

\subsection{Kinetic Studies of Enzyme Inhibition}

The compound $\mathbf{2} \mathbf{i}$, which was found to be the most effective derivative in the series, was included in the enzyme kinetics study to assign the type of inhibition. For this purpose, this compound was prepared at different concentrations $\left(\mathrm{IC}_{50}, 2 \mathrm{xIC}_{50}\right.$ and $\left.\mathrm{IC}_{50} / 2\right)$. Moreover, a substrate (ATC) was used at various concentrations $(600,300,150,75,37.5$, and $18.75 \mu \mathrm{M})$. The enzyme kinetics assay was carried out as in our previous publications [33-40]. Lineweaver-Burk plots were formed using Microsoft Office Excel 2013. The $K_{i}$ values of the compound were easily calculated from the second plot with a common intercept on the $x$-axis (corresponding to $-\mathrm{K}_{\mathrm{i}}$ ).

\subsection{Prediction of ADME Parameters and BBB Permeability}

In order to predict the pharmacokinetic profiles of synthesized compounds 2a-2l, QikProp 4.8 software [41] was used, and their physicochemical parameters were calculated via the in silico method.

\subsection{In Vitro BBB Permeability Assay}

In order to observe the BBB crossing ability of the most active compound $\mathbf{2} \mathbf{i}$, the parallel artificial membrane permeability assay (PAMPA) was performed as previously described [42].

\subsection{Molecular Docking}

A structure-based in silico procedure was applied to discover the binding modes of compounds 2a, 2b, 2d, 2e, 2g, and $\mathbf{2 i}$ to $h \mathrm{AChE}$ enzyme active site. The crystal structures of $h \mathrm{AChE}$ (PDB ID: 4EY7) [22], which was crystallized with donepezil, was retrieved from the Protein Data Bank server (www.pdb.org). The molecular docking procedure was applied as in our previously reported studies [33-40].

\section{Results and Discussion}

\subsection{Chemistry}

In this study, new compounds were synthesized that possessed thiazolylhydrazone moiety. The synthetic route to the obtained compounds $\mathbf{2 a} \mathbf{a}-\mathbf{2 l}$ is presented in the Scheme 1. Substituted thiosemicarbazone derivatives were obtained by reacting the substituted aldehyde derivatives with thiosemicarbazide. The target compounds (2a-21) were synthesized by means of ring closure reaction using thiosemicarbazones (1a-11) and appropriate 2-bromoacetophenone.

The final compounds were purified, and their structures were characterized by spectroscopic methods $\left({ }^{1} \mathrm{H}\right.$ NMR, ${ }^{13} \mathrm{C}$ NMR, and HRMS). In the ${ }^{1} \mathrm{H}$ NMR spectrum, methinic protons had singlet peaks between 7.54 and $7.59 \mathrm{ppm}$. Thiazole NH exhibited broadened singlet peaks between 12.04 and $12.35 \mathrm{ppm}$. In the ${ }^{13} \mathrm{C}$ NMR spectrum, peak splitting was observed due to the C-F coupling. All of the masses were in accordance with the estimated $\mathrm{M}+\mathrm{H}$ values. 


\subsection{Anticholinesterase Enzymes Inhibition Assay}

All of the attained 3-((2-(4-(4-(trifluoromethyl)phenyl)thiazol-2-yl)hydrazineylidene)methyl)substituedphenyl derivatives were investigated with regard to their ability to inhibit the activity of cholinesterase enzymes using the in vitro modified Ellman's spectrophotometric method previously described [33-40].

First, all of the synthesized compounds and reference agents, namely donepezil and tacrine, were subjected to enzyme inhibition assay and prepared at concentrations of $10^{-3}$ and $10^{-4} \mathrm{M}$; thus, the first step of the assay was completed. The enzyme activity results of this step are presented in Table 1. Next, the selected compounds that displayed an inhibition profile of more than $50 \%$ at a concentration of $10^{-4} \mathrm{M}$ were further tested, together with reference agents, at concentrations of $10^{-5}$ to $10^{-9} \mathrm{M}$ to perform the second step of enzyme inhibition assay. Therefore, the $\mathrm{IC}_{50}$ values of the selected compounds and reference agents were calculated. The percent inhibitions (at concentrations of $10^{-3}-10^{-9} \mathrm{M}$ ) and $\mathrm{IC}_{50}$ values are given in Supplementary Material Table S1.

When all of the results were considered, it was observed that none of the synthesized compounds could pass the second step of the enzyme activity assay in terms of BChE enzyme. Only compounds $\mathbf{2 a}, \mathbf{2} \mathbf{b}, \mathbf{2 d}, \mathbf{2 e}, \mathbf{2} \mathbf{g}, \mathbf{2} \mathbf{i}$, and $\mathbf{2 j}$ exhibited more than $50 \%$ inhibitory activity at a concentration of $10^{-3}$ $\mathrm{M}$ against the BChE enzyme. All of the obtained compounds displayed selective inhibition on the AChE. All of the compounds exhibited more than 50\% inhibitory activity at a concentration of $10^{-3} \mathrm{M}$, whereas compounds $\mathbf{2 a}, \mathbf{2} \mathbf{b}, \mathbf{2} \mathbf{d}, \mathbf{2} \mathbf{e}, \mathbf{2} \mathbf{g}, \mathbf{2} \mathbf{i}$, and $\mathbf{2} \mathbf{j}$ could pass the second step of AChE enzyme activity assay, and thus, they were subjected to the detailed inhibition assay. The $\mathrm{IC}_{50}$ values of compounds $\mathbf{2 a}$, $\mathbf{2 b}, \mathbf{2 d}, \mathbf{2 e}, \mathbf{2} \mathbf{g}, \mathbf{2} \mathbf{i}$, and $\mathbf{2 j}$ were calculated as $0.063 \pm 0.003,0.056 \pm 0.002,0.147 \pm 0.006,0.040 \pm 0.001$, $0.031 \pm 0.001,0.028 \pm 0.001$, and $0.138 \pm 0.005 \mu \mathrm{M}$, respectively. It was seen that compounds $\mathbf{2 a}, \mathbf{2} \mathbf{b}$, $\mathbf{2 e}, \mathbf{2} \mathbf{g}$, and $\mathbf{2} \mathbf{i}$ had a better AChE enzyme inhibition profile than compounds $\mathbf{2} \mathbf{d}$ and $\mathbf{2 j}$. Among these derivatives, compound $2 \mathbf{i}$ was found to be the most active agent in the series with an $\mathrm{IC}_{50}$ value of $0.028 \pm 0.001 \mu \mathrm{M}$. It was seen that compound $2 \mathbf{i}$ showed an inhibition profile at a similar rate as the reference drug, donepezil $\left(\mathrm{IC}_{50}\right.$ value $\left.=0.021 \pm 0.001 \mu \mathrm{M}\right)$.

When the most active compounds $\mathbf{2 a}, \mathbf{2} \mathbf{b}, \mathbf{2 e}, \mathbf{2} \mathbf{g}$, and $\mathbf{2} \mathbf{i}$ were analyzed chemically, it was seen that these compounds carried the substituents at the 3rd or 4th or 3rd/4th positions of the phenyl ring. Compounds $\mathbf{2} \mathbf{d}$ and $\mathbf{2} \mathbf{j}$, which showed a moderate inhibition profile, carried the substituents at the 2nd and 2nd/5th positions, respectively. On the other hand, the other inactive compounds $\mathbf{2 c}, \mathbf{2 f}, \mathbf{2 h}$, $\mathbf{2 k}$, and $\mathbf{2 l}$ carried the substituents at the $2 \mathrm{nd} / 3 \mathrm{rd}$ or $3 \mathrm{rd} / 4 \mathrm{th} / 5 \mathrm{th}$ positions of the phenyl ring. It could be suggested that the substituents at the $3 \mathrm{rd}$ or 4 th or $3 \mathrm{rd} / 4$ th positions of the phenyl ring activated the compounds biologically. However, the $2 \mathrm{nd}$, 2nd/3rd, 2nd/5th, and 3rd/4th/5th positions resulted in a decrease in enzyme inhibition. Specifically, it was believed that the 2 nd position and carrying trisubstituents formed steric obstacles conformationally and thus, this situation results in important interactions belonging to these positions to not be created.

\subsection{Kinetic Studies of Enzyme Inhibition}

Enzyme kinetics studies were conducted to determine the mechanism of inhibition of AChE using a procedure similar to that of the inhibition assay for cholinesterase enzymes. These studies were performed with compound $\mathbf{2} \mathbf{i}$, which was found to be the most potent agent. Linear Lineweaver-Burk graphs were used to estimate the type of inhibition of this compound. The velocity curves of the substrates were recorded in the absence and presence of compound $\mathbf{2} \mathbf{i}$. This compound was prepared for enzyme kinetic studies at concentrations of $\mathrm{IC}_{50} / 2, \mathrm{IC}_{50}$, and $2 \mathrm{IC}_{50}$. In each case, the initial velocity measurements were obtained at different substrate (ATC) concentrations ranging from 600 to $18.75 \mu \mathrm{M}$. To calculate the $\mathrm{K}_{\mathrm{i}}$ (intercept on the $x$-axis) values of this compound value, the secondary plots of slope $\left(\mathrm{K}_{\mathrm{m}} / \mathrm{V}_{\max }\right)$ versus varying concentrations $\left(0, \mathrm{IC}_{50} / 2, \mathrm{IC}_{50}\right.$, and $\left.2 \mathrm{IC}_{50}\right)$ were created. The graphical analyses of steady-state inhibition data for compound $\mathbf{2} \mathbf{i}$ are shown in Figure 2. 
Table 1. \% Inhibition and $\mathrm{IC}_{50}$ values of the synthesized compounds, donepezil and tacrine against $\mathrm{AChE}$ and $\mathrm{BChE}$ enzymes.

\begin{tabular}{|c|c|c|c|c|c|c|}
\hline \multirow{2}{*}{ Compounds } & \multicolumn{2}{|c|}{ AChE \% Inhibition } & \multirow{2}{*}{$\mathrm{AChE} \mathrm{IC}_{50}(\mu \mathrm{M})$} & \multicolumn{2}{|c|}{ BChE \% Inhibition } & \multirow{2}{*}{ BChE IC $_{50}(\mu \mathrm{M})$} \\
\hline & $10^{-3} \mathrm{M}$ & $10^{-4} \mathrm{M}$ & & $10^{-3} \mathrm{M}$ & $10^{-4} \mathrm{M}$ & \\
\hline $2 a$ & $93.425 \pm 1.652$ & $90.465 \pm 1.322$ & $0.063 \pm 0.003$ & $52.380 \pm 0.935$ & $42.466 \pm 0.978$ & $>100$ \\
\hline $2 b$ & $90.285 \pm 1.451$ & $82.151 \pm 1.478$ & $0.056 \pm 0.002$ & $55.488 \pm 0.875$ & $40.541 \pm 0.710$ & $>100$ \\
\hline $2 c$ & $78.215 \pm 1.025$ & $45.108 \pm 0.971$ & $>100$ & $43.612 \pm 0.955$ & $32.466 \pm 0.721$ & $>1000$ \\
\hline $2 d$ & $89.462 \pm 2.041$ & $82.445 \pm 1.695$ & $0.147 \pm 0.006$ & $51.950 \pm 0.994$ & $43.795 \pm 0.895$ & $>100$ \\
\hline $2 e$ & $90.611 \pm 1.815$ & $85.387 \pm 1.730$ & $0.040 \pm 0.001$ & $60.150 \pm 1.039$ & $41.575 \pm 0.907$ & $>100$ \\
\hline $2 f$ & $71.658 \pm 1.395$ & $40.487 \pm 0.890$ & $>100$ & $40.858 \pm 0.895$ & $31.495 \pm 0.820$ & $>1000$ \\
\hline $2 g$ & $93.461 \pm 1.632$ & $88.347 \pm 1.604$ & $0.031 \pm 0.001$ & $63.515 \pm 1.155$ & $40.388 \pm 0.845$ & $>100$ \\
\hline $2 \mathrm{~h}$ & $77.561 \pm 1.758$ & $41.947 \pm 0.976$ & $>100$ & $45.795 \pm 0.926$ & $34.306 \pm 0.738$ & $>1000$ \\
\hline $2 \mathbf{i}$ & $95.207 \pm 1.502$ & $92.130 \pm 1.798$ & $0.028 \pm 0.001$ & $65.015 \pm 1.470$ & $41.518 \pm 0.870$ & $>100$ \\
\hline $2 j$ & $91.326 \pm 2.107$ & $84.945 \pm 1.369$ & $0.138 \pm 0.005$ & $50.811 \pm 0.988$ & $39.628 \pm 0.865$ & $>100$ \\
\hline $2 k$ & $65.298 \pm 1.045$ & $40.825 \pm 0.940$ & $>100$ & $40.171 \pm 0.902$ & $25.631 \pm 0.633$ & $>1000$ \\
\hline 21 & $62.797 \pm 1.277$ & $35.369 \pm 0.895$ & $>100$ & $38.654 \pm 0.815$ & $23.208 \pm 0.759$ & $>1000$ \\
\hline Donepezil & $99.254 \pm 2.104$ & $97.426 \pm 1.890$ & $0.021 \pm 0.001$ & - & - & - \\
\hline Tacrine & - & - & - & $98.255 \pm 1.895$ & $95.465 \pm 1.344$ & $0.006 \pm 0.0002$ \\
\hline
\end{tabular}




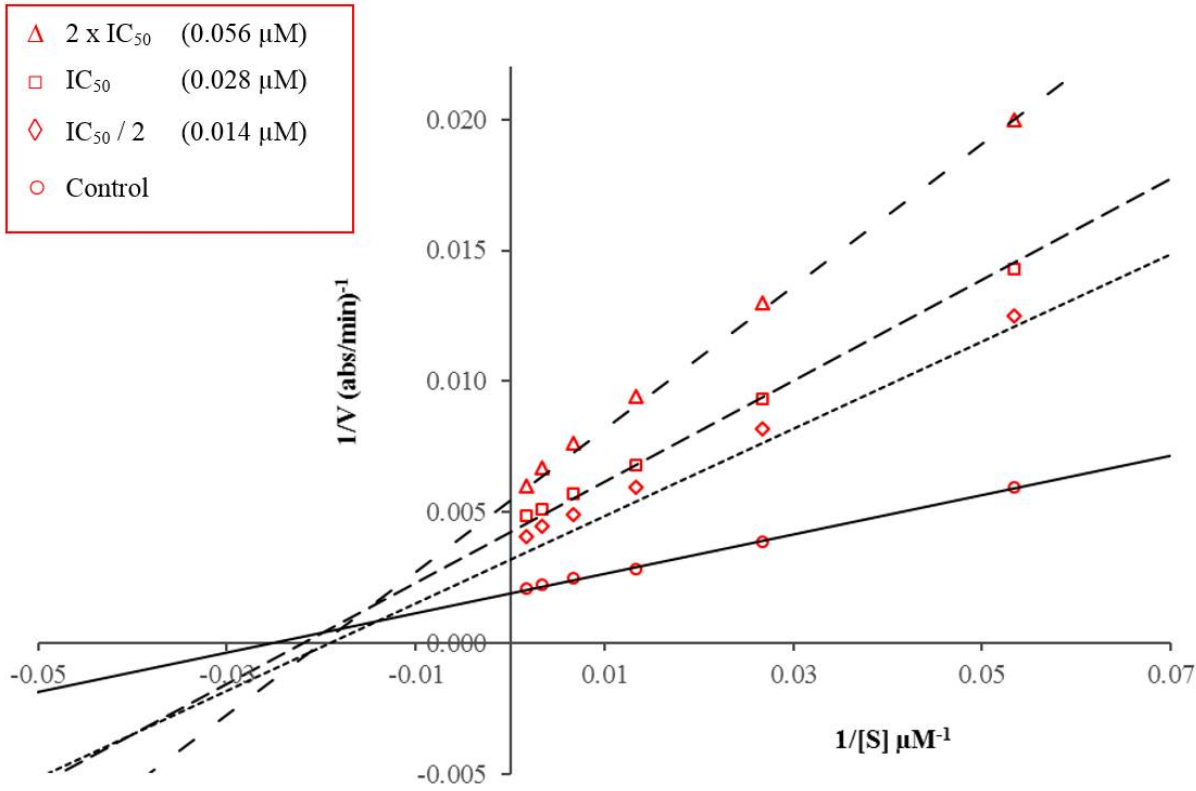

(A)

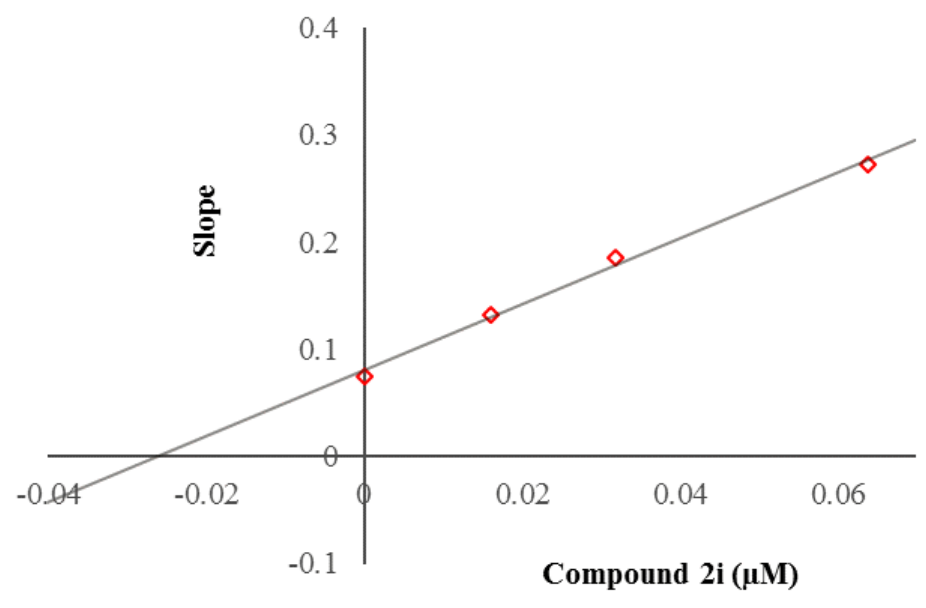

(B)

Figure 2. (A) Lineweaver-Burk plots for the inhibition of AChE by compound 2i. [S], substrate concentration $(\mu \mathrm{M}) ; \mathrm{V}$, reaction velocity $\left(1 / \mathrm{V}(\mathrm{abs} / \mathrm{min})^{-1}\right)$. Inhibitor concentrations are shown at the left. (B) Secondary plot for the calculation of the steady-state inhibition constant $\left(\mathrm{K}_{\mathrm{i}}\right)$ of compound $\mathbf{2 i}$. $\mathrm{K}_{\mathrm{i}}$ was calculated as $0.025 \mu \mathrm{M}$.

According to the Lineweaver-Burk plots, the type of inhibition consists of two general classes: reversible or irreversible. Mixed-type, uncompetitive, competitive, and noncompetitive inhibition types are included in the reversible inhibition [33-40]. As seen in the Lineweaver-Burk plot of compound 2i (Figure 2), a graph with lines that do not intersect at the $x$-axis or the $y$-axis was formed. This observation indicated that compound $2 \mathbf{i}$ was a reversible and mixed-type inhibitor with similar inhibition features as the substrates. Moreover, it was understood that this finding was compatible with the nature of enzyme inhibition of donepezil. It is known that donepezil has a mixed-type inhibition mechanism [43]. Furthermore, the Ki value of compound $2 \mathbf{i}$ was calculated as $0.025 \mu \mathrm{M}$ with the help of a secondary plot.

It is known that reversible enzyme inhibition has advantages compared with the irreversible inhibition type, because non-covalent interactions such as hydrophobic interactions, ionic bonds, 
and hydrogen bonds between the substrate and the enzyme are in question in the reversible inhibition, and these interactions provide the rapid formation and easy breakage of the enzyme-inhibitor complex. Furthermore, reversible inhibitors have a lower risk of side effects than irreversible inhibitors owing to their non-covalent binding ability. Consequently, it can be said that compound $\mathbf{2} \mathbf{i}$, whose inhibition type was determined to be reversible and mixed type, has a pharmaceutical significance and advantage in that it is an inhibitor candidate of the AChE enzyme.

\subsection{Prediction of ADME Parameters and BBB Permeability}

For a compound candidate to become a drug, it should have appropriate pharmacokinetics, in addition to possessing good pharmacological activity and a low toxicity profile. It is also beneficial if, along with good activity, the molecules to be exposed to advanced bioactivity tests have strong bioavailability. In this way, only compounds with strong potential and acceptable pharmacokinetic properties are chosen for research on drug development [44]. Estimates of the absorption, distribution, metabolism, and excretion (ADME) profiles of drug candidates have been made within the scope of computer-aided drug development studies throughout recent years. The ADME estimates provide early warning of developmental difficulties that may arise in the formulation, process development, and safety that will increase the time/cost of the development of the drug and delay clinical entry [45]. They also allow for the precise design and interpretation of drug discovery experiments [46]. Therefore, in this study, the ADME parameters of the synthesized compounds (2a-2l) were evaluated using QikProp 4.8 software (Schrödinger Inc., New York, NY, USA) [41].

In addition to the ADME properties, drug-likeness properties were also estimated using QikProp. The drug-likeness of the compounds was assessed according to Lipinski's rule of 5 and Jorgensen's rule of 3 [47-50]. The calculated ADME parameters are presented in Table 2. It can be seen in Table 2 that all of the parameters are within the reference ranges. In keeping with the rules of 3 and 5, the obtained compounds (2a-2l) were in accordance with the set parameters, as they did not cause more than one violation. Considering the results of the ADME parameter studies, the synthesized compounds were determined to have pharmacokinetic profiles that may be appropriate for clinical use.

Since the molecules are expected to show activity in the central nervous system (CNS) for anti-Alzheimer's efficiency, when the results were analyzed in this respect, it was seen that the predicted CNS activity values of the compounds were between 0 and 1 . The value of 1 on this scale represents positive activity in the CNS. In addition, the $\log \mathrm{P}$ and $\log \mathrm{BB}$ values, which are the guides for the compounds to cross the blood-brain barrier, were in the range of 3.641 to 5.273 and $(-0.756)$ to 0.374, respectively, and they were within the recommended limits [51]. Therefore, it can be considered that the synthesized compounds can exceed the blood-brain barrier (BBB), which is very important for CNS-related drugs.

Considering the results of the ADME and BBB permeability studies, the synthesized compounds were determined to possess pharmacokinetic profiles that may be appropriate for clinical use. 
Table 2. Calculated ADME (absorption, distribution, metabolism, elimination) parameters of compounds 2a-21.

\begin{tabular}{|c|c|c|c|c|c|c|c|c|c|c|c|c|c|c|c|c|c|}
\hline Comp. & MW & RB & DM & MV & DHB & AHB & PSA & $\log P$ & $\log S$ & PCaco & $\log B B$ & PMDCK & CNS & PM & $\%$ HOA & VRF & VRT \\
\hline $2 a$ & 363.357 & 5 & 6.352 & 1073.112 & 2 & 4.750 & 57.634 & 4.295 & -6.085 & 1363.075 & -0.292 & 5986.232 & 0 & 2 & 100 & 0 & 1 \\
\hline $2 b$ & 363.357 & 5 & 8.087 & 1073.112 & 2 & 4.750 & 57.634 & 4.295 & -6.085 & 1363.095 & -0.292 & 5986.324 & 0 & 2 & 100 & 0 & 1 \\
\hline $2 c$ & 379.356 & 6 & 6.600 & 1090.479 & 3 & 5.500 & 77.329 & 3.641 & -5.694 & 602.692 & -0.756 & 2477.781 & 1 & 3 & 100 & 0 & 0 \\
\hline $2 d$ & 377.383 & 5 & 7.236 & 1122.809 & 1 & 4.750 & 42.093 & 5.142 & -6.596 & 4525.117 & 0.293 & 10,000 & 1 & 2 & 100 & 1 & 1 \\
\hline $2 e$ & 377.383 & 5 & 6.313 & 1113.128 & 1 & 4.750 & 43.433 & 5.066 & -6.219 & 4525.117 & 0.313 & 10,000 & 1 & 2 & 100 & 1 & 1 \\
\hline $2 f$ & 407.410 & 6 & 5.347 & 1189.498 & 1 & 5.500 & 50.440 & 5.192 & -6.655 & 4525.108 & 0.231 & 10,000 & 1 & 3 & 100 & 1 & 1 \\
\hline $2 \mathrm{~g}$ & 407.410 & 6 & 7.535 & 1179.309 & 1 & 5.500 & 51.624 & 5.098 & -6.351 & 4525.108 & 0.245 & 10,000 & 1 & 3 & 100 & 1 & 1 \\
\hline $2 \mathrm{~h}$ & 391.367 & 4 & 7.047 & 1084.671 & 1 & 5.500 & 53.698 & 4.576 & -5.904 & 4526.666 & 0.374 & 10,000 & 1 & 1 & 100 & 0 & 1 \\
\hline $2 \mathbf{i}$ & 393.383 & 6 & 7.551 & 1142.737 & 2 & 5.500 & 65.447 & 4.388 & -6.249 & 1454.418 & -0.334 & 6420.985 & 0 & 3 & 100 & 0 & 1 \\
\hline $2 j$ & 393.383 & 6 & 6.825 & 1132.218 & 2 & 5.500 & 64.300 & 4.374 & -5.890 & 1674.494 & -0.220 & 7477.311 & 0 & 3 & 100 & 0 & 1 \\
\hline $2 \mathrm{k}$ & 437.436 & 7 & 7.596 & 1265.955 & 1 & 6.250 & 59.089 & 5.273 & -6.619 & 4525.108 & 0.177 & 10,000 & 1 & 4 & 100 & 1 & 1 \\
\hline 21 & 423.409 & 7 & 5.877 & 1207.466 & 2 & 6.250 & 73.261 & 4.414 & -6.177 & 1428.142 & -0.386 & 6295.69 & 0 & 4 & 100 & 0 & 1 \\
\hline
\end{tabular}

MW: Molecular weight RB: Number of rotatable bonds (recommended value: 0-15) DM: Computed dipole moment (recommended value: 1-12.5) MV: Total solvent-accessible volume (recommended value: 500-2000) DHB: Estimated number of hydrogen bond donors (recommended value: 0-6) AHB: Estimated number of hydrogen bond acceptors (recommended value: 2-20) PSA: Van der Waals surface area of polar nitrogen and oxygen atoms and carbonyl carbon atoms (recommended value: 7-200) logP: Predicted octanol/water partition coefficient (recommended value: -2-6.5) logS: Predicted aqueous solubility (recommended value: $-6.5-0.5)$ PCaco: Predicted apparent Caco-2 cell permeability (recommended value: $<25$ poor, $>500$ great) $\log$ BB: Predicted brain/blood partition coefficient (recommended value: $-3-1.2)$ PMDCK: Predicted apparent MDCK cell permeability (recommended value: <25 poor, $>500$ great) CNS: Predicted central nervous system activity on a -2 (inactive) to +2 (active) scale (recommended value: -2 (inactive), +2 (active)) PM: Number of likely metabolic reactions (recommended value: 1-8) \%HOA: Predicted human oral absorption percent (recommended value: $>80 \%$ is high, $<25 \%$ is poor) VRF: Number of violations of Lipinski's rule of five. The rules are: $\mathrm{MW}<500, \log \mathrm{P}<5, \mathrm{DHB} \leq 5, \mathrm{AHB} \leq 10$, Positive PSA value. VRT: Number of violations of Jorgensen's rule of three. The three rules are: $\operatorname{logS}>-5.7, \mathrm{PCaco}>22 \mathrm{~nm} / \mathrm{s}$, $\mathrm{PM}<7$. 


\subsection{In Vitro BBB Permeability Assay}

The capability of BBB penetration is very important for CNS-related drugs. The most active derivative $2 \mathbf{i}$ was submitted to a PAMPA test to detect its BBB permeability $\left(P_{e}\right)$. The results of this assay can be classified as mentioned in Table 3 [42,52,53]:

Table 3. Type of blood-brain barrier (BBB) penetration of compound $\mathbf{2 i}$.

\begin{tabular}{|c|c|c|c|}
\hline Classification & Type of BBB Permeation & Compound & Type of BBB Permeation \\
\hline CNS+ & $\begin{array}{l}\text { High BBB permeation } \\
P_{e}\left(10^{-6} \mathrm{~cm} \mathrm{~s}^{-1}\right)>4.0\end{array}$ & \multirow{3}{*}{$2 \mathbf{i}$} & \multirow{3}{*}{$\begin{array}{c}\text { CNS+ } \\
\text { High BBB permeation }\end{array}$} \\
\hline CNS $>-$ & $\begin{array}{l}\text { Low BBB permeation } \\
P_{e}\left(10^{-6} \mathrm{~cm} \mathrm{~s}^{-1}\right)<2.0\end{array}$ & & \\
\hline CNS \pm & $\begin{array}{l}\text { BBB permeation uncertain } \\
2.0<P_{e}\left(10^{-6} \mathrm{~cm} \mathrm{~s}^{-1}\right)<4.0\end{array}$ & & \\
\hline
\end{tabular}

According to assay results and above classification, it was found that compound $\mathbf{2} \mathbf{i}$ showed good BBB penetration and thus its ability was evaluated as "CNS+".

\subsection{Molecular Docking}

As described in the inhibition assay for cholinesterase enzymes, compounds $\mathbf{2 a}, \mathbf{2} \mathbf{b}, \mathbf{2 e}, \mathbf{2} \mathbf{g}$, and $\mathbf{2} \mathbf{i}$ were found to be the most active derivatives against the AChE enzyme in the series. Therefore, docking experiments were conducted to determine their inhibition ability in silico. Based on the docking experiments, further information into the binding modes of compounds $\mathbf{2 a}, \mathbf{2} \mathbf{b}, \mathbf{2 e}, \mathbf{2} \mathbf{g}$, and $\mathbf{2 i}$ and assessment of the impact of structural modifications on inhibitory activity against the AChE enzyme could be obtained. Studies were carried out using the X-ray crystal structure of Homo sapiens AChE (hAChE PDB ID:4EY7) [22] retrieved from the Protein Data Bank server (www.pdb.org). This X-ray crystal structure was selected because it is of human nature, has high resolution, and contains a donepezil molecule as the ligand. The rendered docking poses of compounds $\mathbf{2 a}, \mathbf{2} \mathbf{b}, \mathbf{2} \mathbf{e}, \mathbf{2} \mathbf{g}$, and $\mathbf{2} \mathbf{i}$ are given in Figures 3 and 4, Supplementary Material Figures S1-S5.

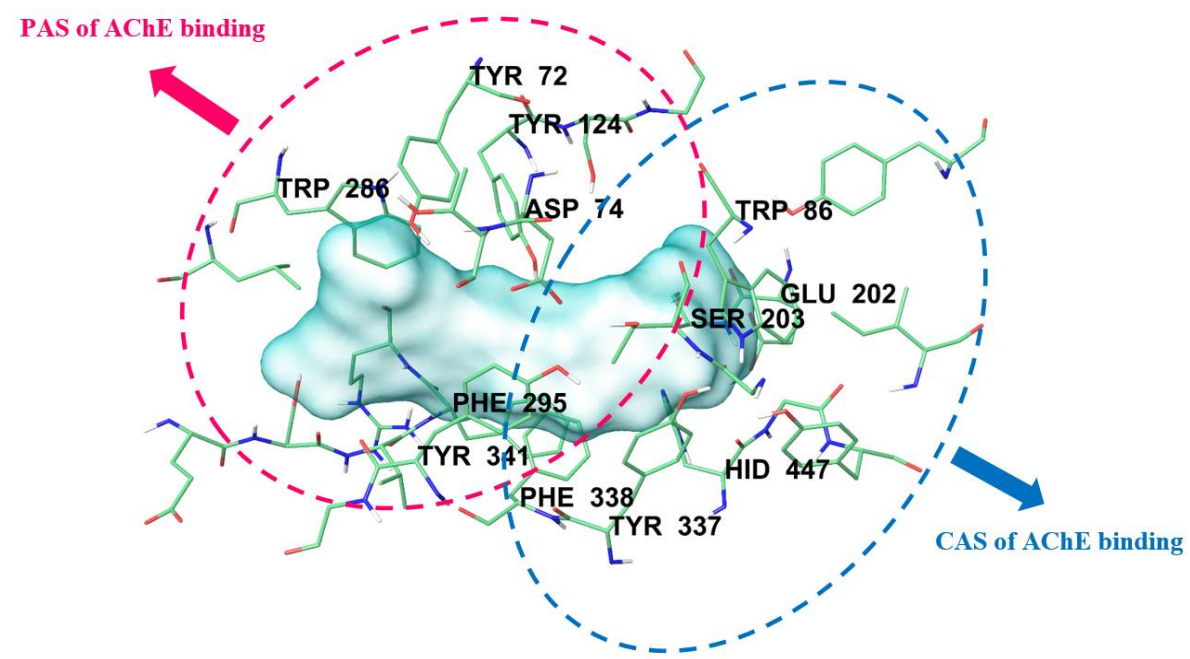

Figure 3. The CAS and PAS regions of AChE enzyme along with the important amino acids. 


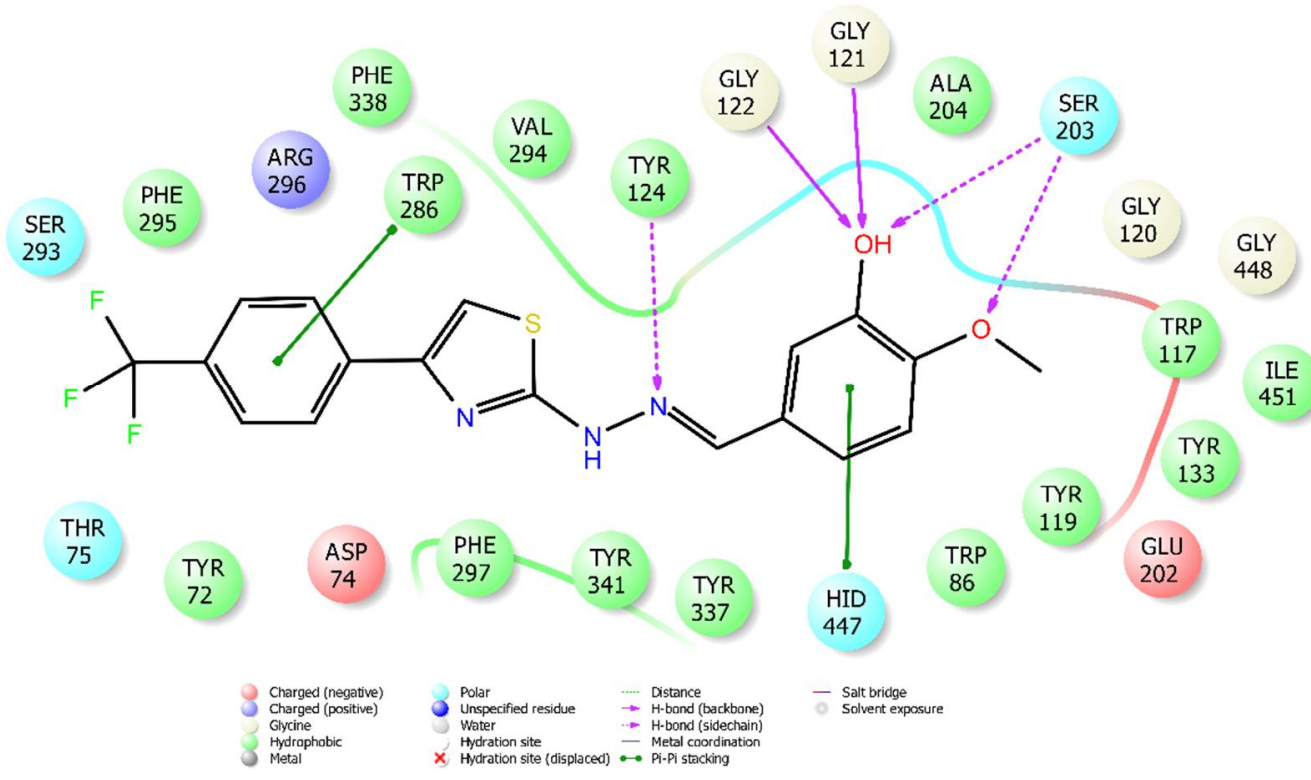

(A)

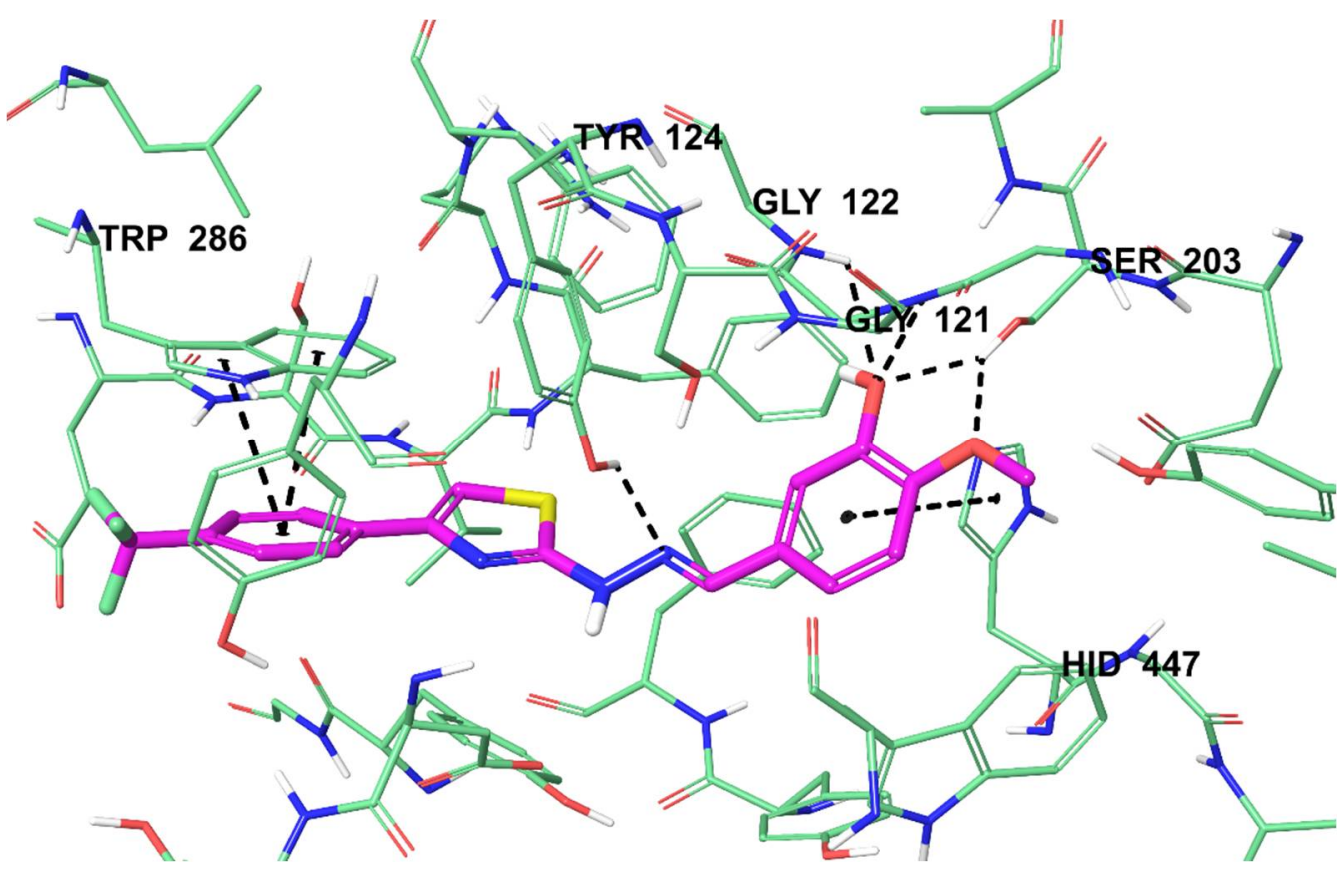

(B)

Figure 4. The two- (A) and three-dimensional (B) interacting mode of compound $2 \mathbf{i}$ in the active region of AChE. The inhibitor and important residues in the active site of enzyme are presented by a tube model colored with purple and aquamarine, respectively (AChE PDB Code: 4EY7).

According to the crystallographic X-ray structure of the AChE (PDB ID:4EY7), the active pocket enzyme consisted of two major binding sites, the CAS and PAS. The CAS contained the residues of amino acids Trp86, Tyr133, Glu202, Ser203, Tyr337, Phe338, and His447, while amino acids Tyr72, Asp74, Tyr124, Trp286, Phe295, and Tyr341 were identified in the PAS [54-57] (Figure 3). Donepezil interacts with both the CAS and PAS. Thus, it can be concordantly settled into the gorge due to its dual binding site functionality $[58,59]$. There is a $\pi-\pi$ interaction between the benzyl of donepezil and the indole of Trp86. Moreover, the formation of cation $-\pi$ interactions are in question between 
the protonated nitrogen atom of piperidine and the indole of Trp86 and the phenyl of Tyr337. Thus, the benzylpiperidine group of donepezil is strongly located in the CAS. The interactions related to the 1-indanone ring are important for binding to the PAS. In this context, Trp286 amino acid is very essential. The indole of this amino acid creates a $\pi-\pi$ interaction with the 1 -indanone ring. Furthermore, a hydrogen bond formation is observed between the carbonyl of the 1-indanone and the amine of Phe295 [22-24,60,61].

Supplementary Material Figure S1 presents the superimposition of compounds $\mathbf{2 a}, \mathbf{2 b}, \mathbf{2 e}, \mathbf{2} \mathbf{g}$, and $\mathbf{2} \mathbf{i}$ in the active region of the AChE. The 2- and 3-dimensional docking poses of compounds $2 \mathbf{a}, \mathbf{2} \mathbf{b}, \mathbf{2 e}$, $\mathbf{2 g}$, and $\mathbf{2 i}$ are given in Figure 4, Supplementary Material Figures S2-S5. As can be seen from the docking studies, the designed and synthesized compounds in this study can be located in the active region, similar to donepezil. According to these poses, the phenyl of the 4-(4-(trifluoromethyl)phenyl)thiazole group creates a $\pi-\pi$ interaction with the indole of Trp286 in compounds $\mathbf{2 e}, \mathbf{2} \mathbf{g}$, and $\mathbf{2 i}$. This $\pi-\pi$ interaction with Trp286 was observed with the thiazole ring of compound $\mathbf{2 a}$. For compound $\mathbf{2 b}$, both of the phenyl and thiazole rings of the 4-(4-(trifluoromethyl)phenyl)thiazole group established $\pi-\pi$ interactions with the phenyl of Tyr341. Moreover, in compound $\mathbf{2 e}$, there was a $\pi-\pi$ interaction between the thiazole ring and the phenyl of Tyr341. All of these interactions described provided insight into how compounds $\mathbf{2 a}, \mathbf{2} \mathbf{b}, \mathbf{2 e}, \mathbf{2} \mathbf{g}$, and $\mathbf{2} \mathbf{i}$ bound to the PAS.

When the interactions were analyzed in terms of binding to the CAS, a $\pi-\pi$ interaction formation was seen between the substituted phenyl ring and the indole of Trp86 in compounds $\mathbf{2 a}$ and $\mathbf{2} \mathbf{b}$. For compounds $\mathbf{2 e}, \mathbf{2} \mathbf{g}$, and $\mathbf{2} \mathbf{i}$, this interaction was observed with the imidazole of Hid447. Furthermore, the phenyl ring of compound $\mathbf{2} \mathbf{g}$ formed the other $\pi-\pi$ interactions with the phenyl of Phe338. Another important interaction of binding to the CAS was the formation of a hydrogen bond with the hydroxyl of Tyr124. This interaction was seen with the nitrogen of hydrazine moiety in compounds $2 \mathbf{a}$ and $\mathbf{2 i}$.

The main chemical structural difference of compounds $\mathbf{2 a}, \mathbf{2} \mathbf{b}, \mathbf{2 e}, \mathbf{2} \mathbf{g}$, and $\mathbf{2} \mathbf{i}$ was the various substituents of the phenyl ring. Compounds $\mathbf{2} \mathbf{a}$ and $\mathbf{2} \mathbf{b}$ had hydroxyl at the $3 \mathrm{rd}$ and 4 th positions of the phenyl, respectively. The hydroxyl of compound 2a created a hydrogen bond with the carbonyl of Asp74; however, two hydrogen bond formations were seen between the hydroxyl in compound $\mathbf{2 b}$ and the amino of Gly120 and the carbonyl of Glu202, respectively. Compound 2e bore a methoxy moiety at the 3rd position of the phenyl, which was different than that of compounds $\mathbf{2 a}$ and $\mathbf{2} \mathbf{b}$. This methoxy established two hydrogen bonds with the amino of Gly121 and the hydroxyl of Ser203. There were two methoxy moieties at the 3rd and 4 th positions of the phenyl in compound $\mathbf{2 g}$. Each of them formed two hydrogen bonds with the hydroxyl of Ser203. Compound $\mathbf{2} \mathbf{i}$ contained hydroxyl and methoxy moieties at the 3rd and 4th positions of the phenyl, respectively. The hydroxyl of compound $2 \mathbf{i}$ created three hydrogen bonds with the hydroxyl of Ser203 and the amino groups of Gly121 and Gly122. Another hydrogen bond was found between the methoxy at the 4th position of the phenyl and the hydroxyl of Ser203.

Consequently, molecular docking studies have shown that the substituents at the 3rd and 4th positions of the phenyl ring contribute positively to enzyme activity. This result supported the finding that compounds $2 \mathbf{g}$ and $\mathbf{2 i}$, which had disubstituents at the $3 \mathrm{rd}$ and 4 th positions, displayed a more potent inhibition profile than compounds $\mathbf{2 a}, \mathbf{2} \mathbf{b}$, and $\mathbf{2 e}$, which carried the substituents at the $3 \mathrm{rd}$ or 4 th positions. Moreover, the reason why compound $2 \mathbf{i}$ was more active than compound $2 \mathbf{g}$ was that it had additional formations of hydrogen bonds belonging to the substituents at the $3 \mathrm{rd}$ and 4 th positions.

Molecular docking studies were carried out in detail using the per-residue interaction panel of Glide to determine the contribution of van der Waals and electrostatic interactions in binding to the enzyme active region. Figure 5 presents the van der Waals and electrostatic interactions of compound $2 \mathbf{i}$, which was found to be the most active agent. It can be seen that this compound had favorable van der Waals interactions with amino acids Tyr72, Trp86, Gly120, Gly121, Tyr124, Glu202, Trp286, Val294, Phe295, Phe297, Tyr337, Phe338, Tyr341, and Hid447, which are displayed in pink and red, as described in the Glide user guide [62]. Similarly, promising electrostatic contributions of compound 2i were determined with amino acids Asp74, Trp86, Gly120, Gly121, Gly122, Tyr124, Ser125, Glu202, 
Ser203, Ala204, Arg296, and Hid447. All of these findings explained why compound 2i exhibited a stronger inhibition profile than the other compounds.

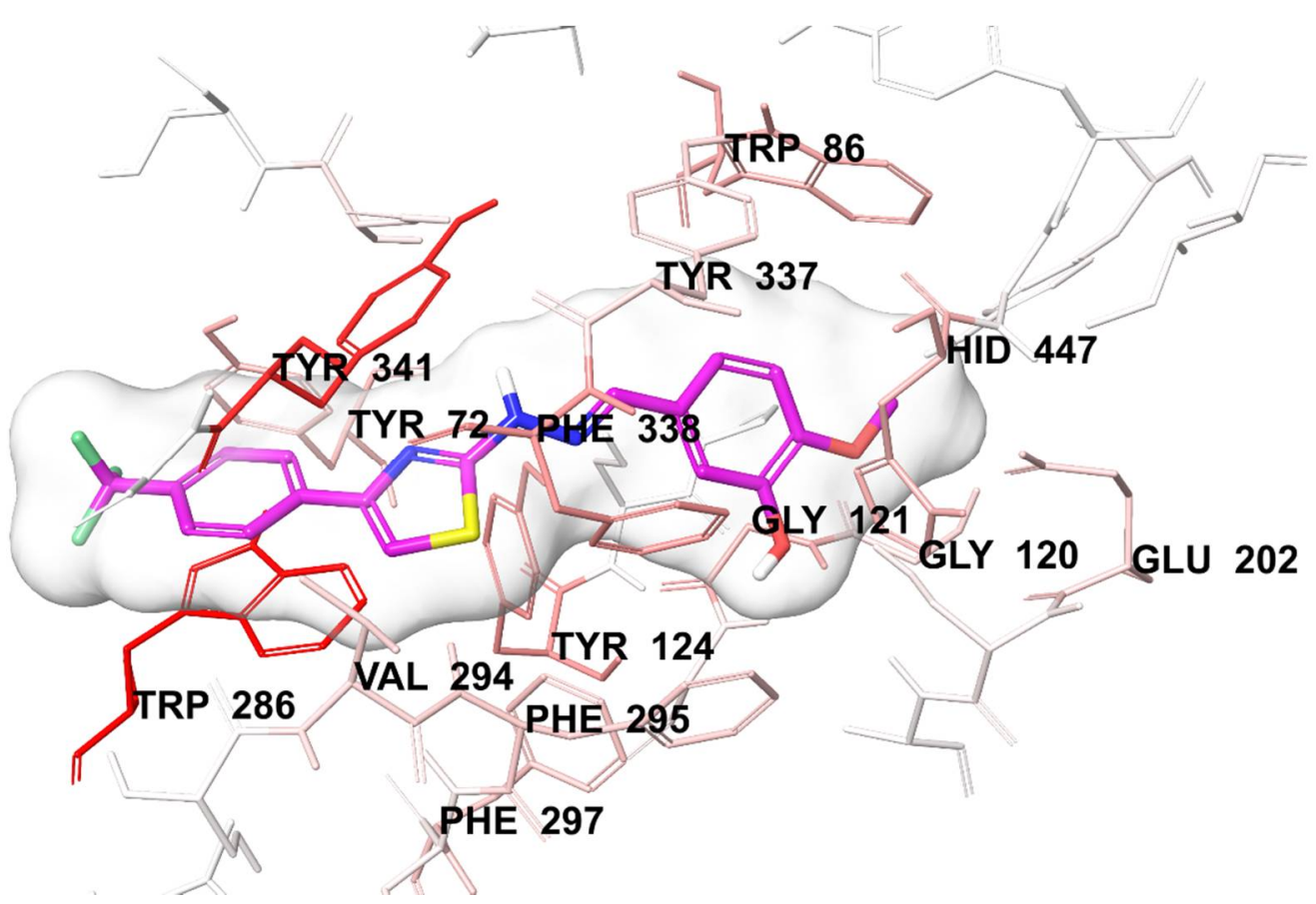

(A)

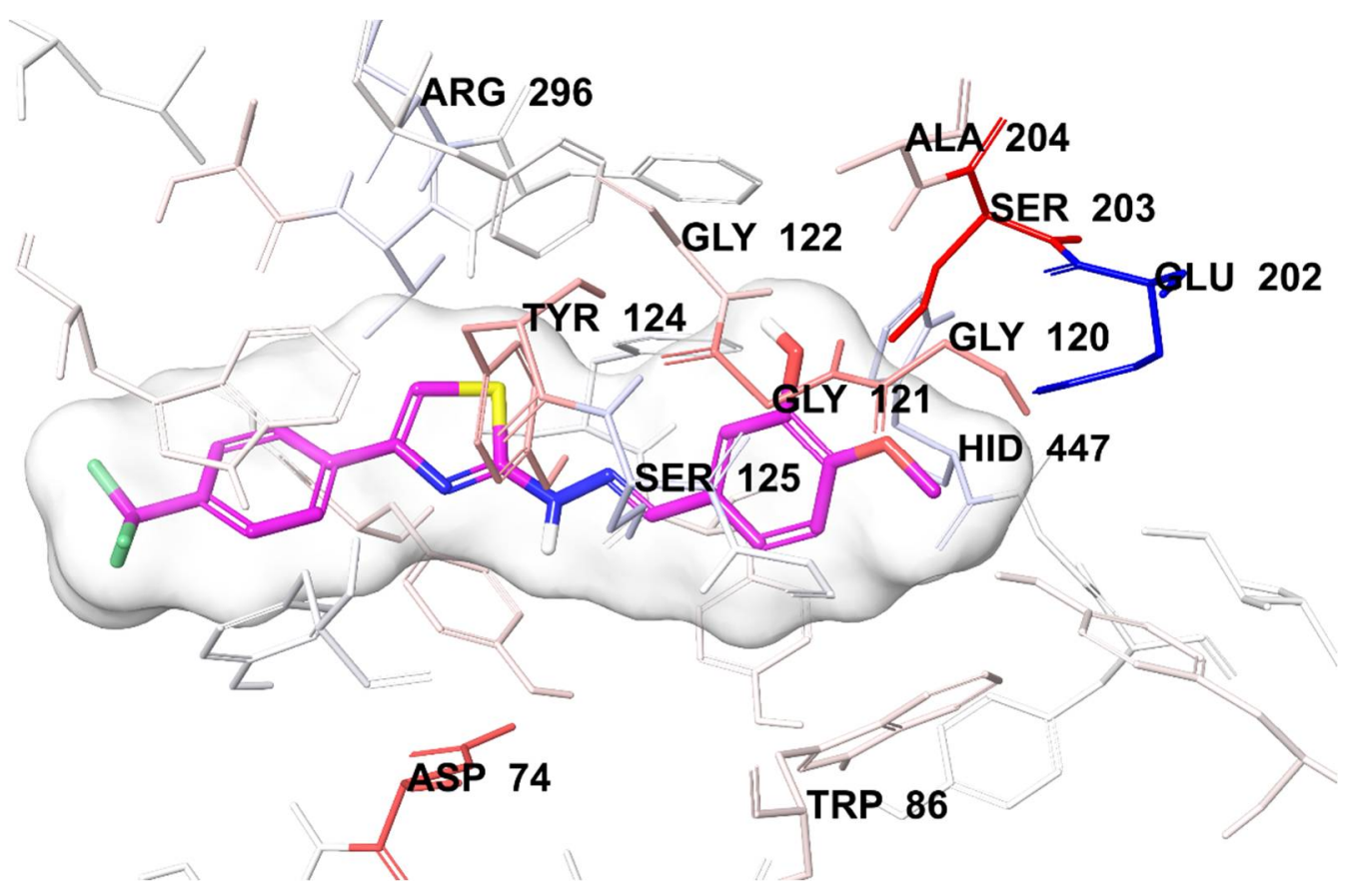

(B)

Figure 5. The van der Waals (A) and electrostatic interactions (B) of compound $2 \mathbf{i}$ with an active region of AChE. The active ligand has a lot of favorable van der Waals and electrostatic interactions. The residues are colored (blue, red, and pink) according to the distance from ligand by per-residue interaction panel. 
Supplementary Material Figure S6 shows the docking pose of compound 2d, which displayed a moderate enzyme inhibitory activity in the series. This compound was subjected to molecular docking studies to explain why it was less active than the other compounds $(\mathbf{2 a}, \mathbf{2 b}, \mathbf{2 e}, \mathbf{2} \mathbf{g}$, and $\mathbf{2 i})$ and what caused this result chemically. When the docking poses of this compound were analyzed, it was seen that there were common interactions related to the 4-(4-(trifluoromethyl)phenyl)thiazole and benzylidenehydrazine groups in terms of binding to the CAS and PAS regions mentioned above. Compound $\mathbf{2 d}$ had a methoxy moiety at the 2 nd position of the phenyl ring, which was different from that of the other compounds $(\mathbf{2} \mathbf{a}, \mathbf{2} \mathbf{b}, \mathbf{2 e}, \mathbf{2} \mathbf{g}$, and $\mathbf{2 i})$. However, the hydrogen bond formations observed at the $3 \mathrm{rd}$ and 4 th positions of other compounds could not be detected at the 2nd position of this compound. The absence of additional interactions belonging to the substituents of the phenyl ring could clarify the decrease in the enzyme inhibitory activity. It was believed that the 2nd position presented a steric obstacle against interaction with any amino acid conformationally. Moreover, it was assumed that this position negatively affected the interaction of the $3 \mathrm{rd} / 4$ th positions of the compounds, which had disubstituents (at the 2nd and 5th positions) and trisubstituents (at the 3rd, 4th, and 5th positions). Therefore, these compounds could only exhibit interactions related to common chemical structures and could not display remarkable enzyme inhibition profiles such as with compounds $\mathbf{2 a}$, $2 \mathbf{b}, 2 \mathrm{e}, 2 \mathrm{~g}$, and $2 \mathbf{i}$.

\section{Conclusions}

The designed 3-((2-(4-(4-(trifluoromethyl)phenyl)thiazol-2-yl)hydrazineylidene)methyl)-substitue dphenyl derivatives as AChE inhibitors were successfully synthesized and analyzed in detail using ${ }^{1} \mathrm{H}$ NMR, ${ }^{13} \mathrm{C}$ NMR, and HRMS spectrometric techniques. It was also concluded that the synthesized compounds presented promising drug-like characteristics and ADME properties with the help of ADME predictions by using QikProp 4.8 software. Their in vitro enzyme inhibitory activity test results showed that none of the compounds exhibited significant enzyme inhibition against the BChE enzyme. Compounds $2 \mathbf{a}, \mathbf{2 b}, \mathbf{2 e}, \mathbf{2} \mathbf{g}$, and $\mathbf{2 i}$ containing the substituents at the $3 \mathrm{rd}$ or 4 th or $3 \mathrm{rd} / 4$ th positions of the phenyl ring displayed the highest $\mathrm{AChE}$ inhibitory activity with the $\mathrm{IC}_{50}$ values of $0.063 \pm 0.003$, $0.056 \pm 0.002,0.040 \pm 0.001,0.031 \pm 0.001$, and $0.028 \pm 0.001 \mu \mathrm{M}$, respectively. This is thought to be caused by that the substituents at the 3rd or 4th or 3rd/4th positions of the phenyl ring, which activated the compounds biologically. Specially, compound $2 \mathbf{i}$ displayed a strong inhibitory activity against $\mathrm{AChE}\left(\mathrm{IC}_{50}=0.028 \pm 0.001 \mu \mathrm{M}\right)$, which had an inhibition profile at a similar rate as the reference drug, donepezil $\left(\mathrm{IC}_{50}\right.$ value $\left.=0.021 \pm 0.001 \mu \mathrm{M}\right)$. This superiority of this compound could be explained by the molecular modeling studies. According to the results of docking studies, compound $2 \mathbf{i}$ bounded to the active site by forming additional interactions via its substituent at the 3rd and 4th positions with Gly121, Gly122, and Ser203 amino acids. In summary, structural modifications can be further made on the basis of the new thiazolylhydrazone derivatives to seek compounds having higher inhibitory activity against $\mathrm{ChE}$ enzymes. All these findings encourage medicinal chemists to explore more structures based on thiazolylhydrazone derivatives for high-efficiency $\mathrm{ChE}$ inhibitors. New chemical modifications can be designed based on this paper so that novel effective derivatives may be subject to future studies. Hence, studies to develop new candidates that may be effective in Alzheimer's disease can be followed rationally.

Supplementary Materials: The following are available online, Table S1. IC 50 values of compounds $2 \mathbf{a}, \mathbf{2 b}, \mathbf{2 d}$, $\mathbf{2 e}, \mathbf{2} \mathbf{g}, \mathbf{2} \mathbf{i}, \mathbf{2} \mathbf{j}$ and donepezil against AChE. Figure S1. The superimposition pose of selected compounds in the enzyme active site (AChE PDB Code: 4EY7). Figure S2. The two- (A) and three-dimensional (B) interacting mode of compound $2 \mathrm{a}$ in the active region of AChE. The inhibitor and important residues in the active site of enzyme are presented by tube model and colored with grey and aquamarine, respectively (AChE PDB Code: 4EY7). Figure S3. The two- (A) and three-dimensional (B) interacting mode of compound $\mathbf{2 b}$ in the active region of AChE. The inhibitor and important residues in the active site of enzyme are presented by tube model and colored with blue and aquamarine, respectively (AChE PDB Code: 4EY7). Figure S4. The two- (A) and three-dimensional (B) interacting mode of compound $2 \mathbf{e}$ in the active region of AChE. The inhibitor and important residues in the active site of enzyme are presented by tube model and colored with orange and aquamarine, respectively (AChE PDB Code: 4EY7). Figure S5. The two- (A) and three-dimensional (B) interacting mode of compound $\mathbf{2 g}$ in the 
active region of AChE. The inhibitor and important residues in the active site of enzyme are presented by tube model and colored with dark green and aquamarine, respectively (AChE PDB Code: 4EY7). Figure S6. The two(A) and three-dimensional (B) interacting mode of compound $\mathbf{2 d}$ in the active region of AChE. The inhibitor and important residues in the active site of enzyme are presented by tube model and colored with pink and aquamarine, respectively (AChE PDB Code: 4EY7). Figure S7. The thin-layer chromatography of the synthesized compounds. Figure S8. Purity of compound 2i. Figure S9. ${ }^{1} \mathrm{H}$ NMR spectra of the compound 2 i. Figure S10. ${ }^{13} \mathrm{C}$ NMR spectra of the compound 2i. Figure S11. HRMS spectra of the compound $2 \mathbf{i}$.

Author Contributions: Y.Ö. and Z.A.K. conceived and designed the experiments; B.N.S. performed the synthesis, activity tests and molecular docking studies; D.O., U.A.Ç. and B.K.Ç. performed the synthesis; D.O. and S.L. performed analysis studies; B.N.S., D.O., U.A.Ç., S.L., B.K.Ç., Y.Ö. and Z.A.K. wrote the paper. All authors have read and agreed to the published version of the manuscript.

Funding: This study was financially supported by Anadolu University Scientific Projects Fund, Project No: 2005 S054.

Conflicts of Interest: The authors declare no conflict of interest.

\section{References}

1. Kalaria, R.N.; Maestre, G.E.; Arizaga, R.; Friedland, R.P.; Galasko, D.; Hall, K.; Luchsinger, J.A.; Ogunniyi, A.; Perry, E.K.; Potocnik, F.; et al. Alzheimer's disease and vascular dementia in developing countries: Prevalence, management, and risk factors. Lancet Neurol. 2008, 7, 812-826. [CrossRef]

2. $\quad$ Rodgers, A.B. Alzheimer's Disease: Unraveling the Mystery; Publication Number: 02-3782; National Institutes of Health Publications: Bethesda, MD, USA, 2002.

3. Huber, A.; Stuchbury, G.; Bürkle, A.; Burnell, J.; Münch, G. Neuroprotective therapies for Alzheimer's disease. Curr. Pharm. Des. 2006, 12, 705-717. [CrossRef] [PubMed]

4. Smith, D.G.; Cappai, R.; Barnham, K.J. The redox chemistry of the Alzheimer's disease amyloid $\beta$ peptide. Biomembranes 2007, 768, 1976-1990. [CrossRef] [PubMed]

5. Craig, L.A.; Hong, N.S.; McDonald, R.J. Revisiting the cholinergic hypothesis in the development of Alzheimer's disease. Neurosci. Biobehav. Rev. 2011, 35, 1397-1409. [CrossRef]

6. Hardy, J.; Selkoe, D.J. The amyloid hypothesis of Alzheimer's disease: Progress and problems on the road to therapeutics. Science 2002, 297, 353-356. [CrossRef]

7. Su, B.; Wang, X.; Nunomura, A.; Moreira, P.I.; Lee, H.G.; Perry, G.; Smith, M.A.; Zhu, X. Oxidative stress signaling in Alzheimer's disease. Curr. Alzheimer Res. 2008, 5, 525-532. [CrossRef]

8. Holmes, C. Systemic inflammation and a lzheimer's disease. Neuropathol. Appl. Neurobiol. 2013, 39, 51-68. [CrossRef]

9. Greenough, M.A.; Camakaris, J.; Bush, A.I. Metal dyshomeostasis and oxidative stress in Alzheimer's disease. Neurochem. Int. 2013, 62, 540-555. [CrossRef]

10. Bajda, M.; Więckowska, A.; Hebda, M.; Guzior, N.; Sotriffer, C.A.; Malawska, B. Structure-based search for new inhibitors of cholinesterases. Int. J. Mol. Sci. 2013, 14, 5608-5632. [CrossRef]

11. Mason, J.M.; Kokkoni, N.; Stott, K.; Doig, A.J. Design strategies for anti-amyloid agents. Curr. Opin. Struct. Biol. 2013, 13, 526-532. [CrossRef]

12. Shukla, V.; Skuntz, S.; Pant, H.C. Deregulated Cdk5 activity is involved in inducing Alzheimer's disease. Arch. Med. Res. 2013, 43, 655-662. [CrossRef] [PubMed]

13. Atri, A.; Frölich, L.; Ballard, C.; Tariot, P.N.; Molinuevo, J.L.; Boneva, N.; Windfeld, K.; Raket, L.L.; Cummings, J.L. Effect of idalopirdine as adjunct to cholinesterase inhibitors on change in cognition in patients with Alzheimer disease: Three randomized clinical trials. JAMA 2018, 319, 130-142. [CrossRef] [PubMed]

14. Lahiri, D.K.; Farlow, M.R.; Greig, N.H.; Sambamurti, K. Current drug targets for Alzheimer's disease treatment. Drug Dev. Res. 2002, 56, 267-281. [CrossRef]

15. Bajda, M.; Guzior, N.; Ignasik, M.; Malawska, B. Current drug targets for Alzheimer's disease treatment. Curr. Med. Chem. 2011, 18, 4949-4975. [CrossRef]

16. Alagille, D.; DaCosta, H.; Baldwin, R.M.; Tamagnan, G.D. 2-Arylimidazo [2, 1-b] benzothiazoles: A new family of amyloid binding agents with potential for PET and SPECT imaging of Alzheimer's brain. Bioorg. Med. Chem. Lett. 2011, 21, 2966-2968. [CrossRef]

17. Gan, C.; Zhou, L.; Zhao, Z.; Wang, H. Benzothiazole Schiff-bases as potential imaging agents for $\beta$-amyloid plaques in Alzheimer's disease. Med. Chem. Res. 2013, 22, 4069-4074. [CrossRef] 
18. Xie, Y.; Deng, S.; Chen, Z.; Yan, S.; Landry, D.W. Identification of small-molecule inhibitors of the A $\beta-A B A D$ interaction. Bioorg. Med. Chem. Lett. 2006, 16, 4657-4660. [CrossRef]

19. Youssef, K.M.; Fawzy, I.M.; El-Subbagh, H.I. N-substituted-piperidines as Novel Anti-alzheimer Agents: Synthesis, antioxidant activity, and molecular docking study. Future J. Pharm. Sci. 2018, 4, 1-7. [CrossRef]

20. Silva, D.; Chioua, M.; Samadi, A.; Agostinho, P.; Garcão, P.; Lajarín-Cuesta, R.; de los Ríos, C.; Iriepa, I.; Moraleda, I.; Gonzalez-Lafuente, L.; et al. Synthesis, pharmacological assessment, and molecular modeling of acetylcholinesterase/butyrylcholinesterase inhibitors: Effect against amyloid- $\beta$-induced neurotoxicity. ACS Chem. Neurosci. 2013, 4, 547-565. [CrossRef]

21. Lan, J.S.; Zhang, T.; Liu, Y.; Yang, J.; Xie, S.S.; Liu, J.; Miao, Z.Y.; Ding, Y. Design, synthesis and biological activity of novel donepezil derivatives bearing N-benzyl pyridinium moiety as potent and dual binding site acetylcholinesterase inhibitors. Eur. J. Med. Chem. 2017, 133, 184-196. [CrossRef]

22. Cheung, J.; Rudolph, M.J.; Burshteyn, F.; Cassidy, M.S.; Gary, E.N.; Love, J.; Matthew, C.F.; Height, J.J. Structures of human acetylcholinesterase in complex with pharmacologically important ligands. J. Med. Chem. 2012, 55, 10282-10286. [CrossRef] [PubMed]

23. Huang, C.S.; Tu, W.T.; Luo, M.; Shi, J.G. Molecular Docking and Design of Novel Heterodimers of Donepezil and Huperzine Fragments as Acetylcholinesterase Inhibitors. Chin. J. Struct. Chem. 2016, 35, 839-848.

24. Vitorovic-Todorovic, M.D.; Koukoulitsa, C.; Juranic, I.O.; Mandic, L.M.; Drakulic, B.J. Structural Modifications of 4-Aryl-4-Oxo-2-Aminylbutanamides and Their Acetyl-and Butyrylcholinesterase Inhibitory Activity. Investigation of AChE-Ligand Interactions by Docking Calculations and Molecular Dynamics Simulations. Supplementary data for the article. Eur. J. Med. Chem. 2014, 81, 158-175. [CrossRef]

25. Neochoritis, C.; Tsoleridis, C.A.; Stephanidou-Stephanatou, J. 1-Arylaminoimidazole-2-thiones as intermediates in the synthesis of imidazo [2,1-b][1,3,4] thiadiazines. Tetrahedron 2008, 64, 3527-3533. [CrossRef]

26. Ibrar, A.; Khan, A.; Ali, M.; Sarwar, R.; Mehsud, S.; Farooq, U.; Halimi, M.A.S.; Khan, I.; Al-Harrasi, A. Combined in vitro and in silico studies for the anticholinesterase activity and pharmacokinetics of coumarinyl thiazoles and oxadiazoles. Front. Chem. 2018, 6, 61-72. [CrossRef] [PubMed]

27. Tripathi, R.K.P.; Sasi, M.V.; Gupta, S.K.; Krishnamurthy, S.; Ayyannan, S.R. Design, synthesis, and pharmacological evaluation of 2-amino-5-nitrothiazole derived semicarbazones as dual inhibitors of monoamine oxidase and cholinesterase: Effect of the size of aryl binding site. J. Enzyme Inhib. Med. Chem. 2018, 33, 37-57. [CrossRef] [PubMed]

28. Ma, Z.Y.; Yang, Q.; Zhang, Y.G.; Li, J.J.; Yang, G.L. Design, synthesis and evaluation of N-acyl-4-phenylthiazole2-amines as acetylcholinesterase inhibitors. Acta Pharm. Sin. 2014, 49, 813-818.

29. Tian, Y.F.; Chen, J.T.; Li, J.J.; Zhang, Y.C.; Cao, T.T.; Ma, Z.Y. Design, synthesis and evaluation of new L-proline derivatives as acetylcholinesterase inhibitors. Acta Pharm. Sin. 2015, 50, 719-724.

30. Zhang, X.Z.; Xu, Y.; Jian, M.M.; Yang, K.; Ma, Z.Y. Synthesis, in vitro assays, molecular docking, theoretical ADMET prediction, and evaluation of 4-methoxy-phenylthiazole-2-amine derivatives as acetylcholinesterase inhibitors. Med. Chem. Res. 2019, 28, 1683-1693. [CrossRef]

31. Xu, Y.; Jian, M.M.; Han, C.; Yang, K.; Bai, L.; Cao, F.; Ma, Z.Y. Design, synthesis and evaluation of new 4-arylthiazole-2-amine derivatives as acetylcholinesterase inhibitors. Bioorg. Med. Chem. Lett. 2020, 30, 126985. [CrossRef]

32. Ellman, G.L.; Courtney, K.D.; Andres, V., Jr.; Feather-Stone, R.M. A new and rapid colorimetric determination of acetylcholinesterase activity. Biochem. Pharmacol. 1961, 7, 88-95. [CrossRef]

33. Saglık, B.N.; Ilgın, S.; Ozkay, Y. Synthesis of new donepezil analogues and investigation of their effects on cholinesterase enzymes. Eur. J. Med. Chem. 2016, 124, 1026-1040. [CrossRef] [PubMed]

34. Demir Özkay, Ü.; Can, Ö.D.; Sağlık, B.N.; Acar Çevik, U.; Levent, S.; Özkay, Y.; Ilgın, S.; Atlı, Ö. Design, synthesis, and AChE inhibitory activity of new benzothiazole-piperazines. Bioorg. Med. Chem. Lett. 2016, 26, 5387-5394. [CrossRef] [PubMed]

35. Acar Çevik, U.; Levent, S.; Sağlık, B.N.;Özkay, Y.; Kaplancıklı, Z.A. Synthesis of Novel 4-(Dimethylaminoalkyl) piperazine-1-carbodithioa te Derivatives as Cholinesterase Inhibitors. Lett. Drug Des. Discov. 2017, 14, 528-539. [CrossRef]

36. Levent, S.; Acar Çevik, U.; Sağlık, B.N.; Özkay, Y.; Can, Ö.D.; Demir Özkay, Ü.; Uçucu, Ü. Anticholinesterase activity screening of some novel dithiocarbamate derivatives including piperidine and piperazine moieties. Phosphorus Sulfur Silicon Relat. Elem. 2017, 192, 469-474. [CrossRef] 
37. Hussein, W.; Sağlık, B.N.; Levent, S.; Korkut, B.; Ilgın, S.; Özkay, Y.; Kaplancıkl1, Z.A. Synthesis and biological evaluation of new cholinesterase inhibitors for Alzheimer's disease. Molecules 2018, 23, 2033. [CrossRef]

38. Tok, F.; Koçyiğit Kaymakçıŏlu, B.; Sağlık, B.N.; Levent, S.; Özkay, Y.; Kaplancıklı, Z.A. Synthesis and biological evaluation of new pyrazolone Schiff bases as monoamine oxidase and cholinesterase inhibitors. Bioorg. Chem. 2019, 84, 41-50. [CrossRef]

39. Acar Çevik, U.; Sağlık, B.N.; Levent, S.; Osmaniye, D.; Kaya Çavuşoğlu, B.; Özkay, Y.; Kaplancıklı, Z.A. Synthesis and AChE-inhibitory activity of new benzimidazole derivatives. Molecules 2019, 24, 861. [CrossRef]

40. Osmaniye, D.; Sağlık, B.N.; Acar Çevik, U.; Levent, S.; Kaya Çavuşoğlu, B.; Özkay, Y.; Kaplancıklı, Z.A.; Turan-Zitouni, G. Synthesis and AChE inhibitory activity of novel thiazolylhydrazone derivatives. Molecules 2019, 24, 2392. [CrossRef]

41. QikProp, version 4.8; Schrödinger, LLC.: New York, NY, USA, 2016.

42. Yan, G.; Hao, L.; Niu, Y.; Huang, W.; Wang, W.; Xu, F.; Liang, L.; Wang, C.; Jin, H.; Xu, P. 2-Substitutedthio-N-(4-substituted-thiazol/1H-imidazol-2-yl) acetamides as BACE1 inhibitors: Synthesis, biological evaluation and docking studies. Eur. J. Med. Chem. 2017, 137, 462-475. [CrossRef]

43. Caliandro, R.; Pesaresi, A.; Cariati, L.; Procopio, A.; Oliverio, M.; Lamba, D. Kinetic and structural studies on the interactions of Torpedo californica acetylcholinesterase with two donepezil-like rigid analogues. J. Enzyme Inhib. Med. Chem. 2018, 33, 794-803. [CrossRef] [PubMed]

44. Henchoz, Y.; Bard, B.; Guillarme, D.; Carrup, P.A.; Veuthey, J.L.; Martel, S. Analytical tools for the physicochemical profiling of drug candidates to predict absorption/distribution. Anal. Bioanal. Chem. 2009, 394, 707-729. [CrossRef] [PubMed]

45. Kerns, E.H. High throughput physicochemical profiling for drug discovery. J. Pharm. Sci. 2001, 90, 1838-1858. [CrossRef] [PubMed]

46. Kerns, E.H.; Di, L. Physicochemical profiling: Overview of the screens. Drug Discov. Today Technol. 2004, 1, 343-348. [CrossRef]

47. Lipinski, C.A.; Franco, L.; Dominy, B.W.; Feeney, P.J. Experimental and computational approaches to estimate solubility and permeability in drug discovery and development settings. Adv. Drug Deliv. Rev. 1997, 23, 3-25. [CrossRef]

48. Jorgensen, W.L.; Duffy, E.M. Prediction of drug solubility from structure. Adv. Drug Deliv. Rev. 2002, 54, 355-366. [CrossRef]

49. Daina, A.; Michielin, O.; Zoete, V. SwissADME: A free web tool to evaluate pharmacokinetics, drug-likeness and medicinal chemistry friendliness of small molecules. Sci. Rep. 2017, 7, 1-13. [CrossRef]

50. Dunitz, J.D.; Taylor, R. Organic fluorine hardly ever accepts hydrogen bonds. Chem-A Eur. J. Med. Chem. 1997, 3, 89-98. [CrossRef]

51. Dvira, H.; Silman, I.; Harel, M.; Rosenberry, T.L.; Sussman, J.L. Acetylcholinesterase: From 3D structure to function. Chem. Biol. Interact. 2010, 187, 10-22. [CrossRef]

52. Di, L.; Kerns, E.H.; Fan, K.; McConnell, O.J.; Carter, C.T. High throughput artificial membrane permeability assay for blood-brain barrier. Eur. J. Med. Chem. 2003, 38, 223-232. [CrossRef]

53. Ning, X.; Guo, Y.; Wang, X.; Ma, X.; Tian, C.; Shi, X.; Zhu, R.; Cheng, C.; Du, Y.; Ma, Z.; et al. Design, synthesis, and biological evaluation of (e)-3, 4-dihydroxystyryl aralkyl sulfones and sulfoxides as novel multifunctional neuroprotective agents. J. Med. Chem. 2014, 57, 4302-4312. [CrossRef] [PubMed]

54. Colovic, M.B.; Krstic, D.; Lazarevic-Pactil, T.; Bondzic, A.M.; Vasic, V. Acetylcholinesterase inhibitors: Pharmacology and toxicology. Curr. Neuropharmacol. 2013, 11, 315-335. [CrossRef] [PubMed]

55. Atanasova, M.; Stavrakov, G.; Philipova, L.; Zheleva, D.; Yordanov, N.; Doytchinova, I. Galantamine derivatives with indole moiety: Docking, design, synthesis and acetylcholinesterase inhibitory activity. Bioorg. Med. Chem. 2015, 23, 5382-5389. [CrossRef] [PubMed]

56. Wu, M.Y.; Esteban, G.; Brogi, S.; Shionoya, M.; Wang, I.; Campiani, G.; Unzeta, M.; Inokuchi, T.; Butini, S.; Marco-Contelles, J. Donepezil-like multifunctional agents: Design, synthesis, molecular modeling and biological evaluation. Eur. J. Med. Chem. 2015, 121, 864-879. [CrossRef]

57. Genest, D.; Rochais, C.; Lecoutey, C.; Jana Sopkova-de Oliveira, S.; Ballandonne, C.; Butt-Gueulle, S.; Legay, R.; Since, M.; Dallemagne, P. Design, synthesis and biological evaluation of novel indano-and thiaindano-pyrazoles with potential interest for Alzheimer's disease. Med. Chem. Commun. 2013, 4, 925-931. [CrossRef] 
58. Al-Rashid, Z.F.; Hsung, R.P. A computational view on the significance of E-ring in binding of (+)-arisugacin A to acetylcholinesterase. Bioorg. Med. Chem. 2015, 25, 4848-4853. [CrossRef]

59. Alipour, M.; Khoobi, M.; Foroumadi, A.; Nadri, H.; Moradi, A.; Sakhteman, A.; Ghandi, M.; Shafiee, A. Novel coumarin derivatives bearing N-benzyl pyridinium moiety: Potent and dual binding site acetylcholinesterase inhibitors. Bioorg. Med. Chem. 2012, 20, 7214-7222. [CrossRef]

60. Cheung, J.; Gary, E.N. Structures of human acetylcholinesterase bound to dihydrotanshinone I and territrem B show peripheral site flexibility. ACS Med. Chem. Lett. 2013, 4, 1091-1096. [CrossRef]

61. Chiou, S.Y.; Huang, C.F.; Hwang, M.T.; Lin, G. Comparison of Active Sites of Butyrylcholinesterase and Acetylcholinesterase Based on Inhibition by Geometric Isomers of Benzene-di-N-Substituted Carbamates. J. Biochem. Molecular Toxicology 2009, 23, 303-308. [CrossRef]

62. Glide; Version 7.1; Schrödinger, LLC.: New York, NY, USA, 2016.

(C) 2020 by the authors. Licensee MDPI, Basel, Switzerland. This article is an open access article distributed under the terms and conditions of the Creative Commons Attribution (CC BY) license (http://creativecommons.org/licenses/by/4.0/). 